\title{
Natural factors and chemical contamination control the structure of macrobenthic communities in the Santos Estuarine System (SP, Brazil)
}

\author{
D. M. S. Abessa1,2,6, B. R. F. Rachid'2,3, L. P. Zaroni², M. R. Gasparro², Y. A. Pinto², \\ M. C. Bícego², M. A. Hortellan4, J. E. S Sarkis4, P. Muniz5, L. B. Moreira1 \\ and E. C. P. M. Sousa ${ }^{2}$ \\ ${ }^{1}$ UNESP Campus do Litoral Paulista. Praça Infante Dom Henrique, s/n., São Vicente, SP, Brazil. 11330-900 \\ 2Instituto Oceanográfico da USP. Praça do Oceanográfico, 191. São Paulo, SP, Brazil. 05508-900 \\ ${ }^{3}$ BR Ambiental. Rua Corinto, 739, sala 91-a, São Paulo, SP, Brazil, 05586-069 \\ ${ }^{4}$ Instituto de Pesquisas Energéticas Nucleares, Av. Prof. Lineu Prestes, 2242, 05508-900 São Paulo - SP, Brazil \\ ${ }_{5}^{5}$ Sección Oceanología, Facultad de Ciencias - UdelaR, Iguá 4225, Montevideo, 11400, Uruguay \\ ${ }^{6}$ Corresponding author.Tel.: +551335697119; Email: denis.abessa@unesp.br
}

Keywords: Benthos; Distribution; Macrofauna; Pollution; Santos Estuarine System.

\begin{abstract}
The Santos Estuarine System (SES) is a complex of bays, islands, estuarine channels, and rivers located on the Southeast coast of Brazil, in which multiple contaminant sources are situated in close proximity to mangroves and other protected areas. In this study, the composition and structure of the macrobenthic communities of SES were described and ninetynine species were identified, with the predominance of polychaetes and bivalve mollusks. The benthic assemblages also showed strong signs of stress, as indicated by the low abundance, richness and diversity, and the dominance of opportunistic species. Integrated analysis including sediment characteristics related to natural and anthropogenic factors (e.g., sediment chemistry, and toxicity) indicated that benthic fauna from the inner portions of the SES and vicinities of the SSOS diffusers as Santos Bay were affected. Some locations at the mouths of Santos and Sao Vicente estuaries exhibited moderate disturbance. In other sites from the mouth of São Vicente and Bertioga channels, and Santos Bay, the benthic fauna were considered not degraded. Our results suggest that a combination of both environmental factors and contaminants were responsible for the benthic community structure.
\end{abstract}

\begin{abstract}
Abbreviations: AH - aliphatic hydrocarbon; ANOVA - Analysis of variance; CEC - Compounds of emerging concern; DO - Dissolved oxygen; LOE - Lines of evidence; PAH - polycyclic aromatic hydrocarbon; MBAS - Methylene Blue Active Substance; nMDS - Non-metric multidimensional scaling; NOEC - No effective concentration; PCA - principal component analysis; PEL - Probable Effect Level; QA/QC - Quality Assurance and Quality Control procedure; SES - Santos Estuarine System; SSOS - Santos Sewage Outfall System; SQT - Sediment quality triad; TEL - Threshold Effect Levels; TOC - total organic carbon.
\end{abstract}

Nomenclature: Day (1967), Amaral (1980), Nonato (1981), Amaral and Nonato (1982, 1984), Lana (1984), Bolívar and Lana (1986), Amaral and Nonato $(1994,1996)$ for polychaetes, Rios (1984) for mollusks, Young (1998) for crustaceans, Borges et al (2002) for ophiuroids, and Migotto (1996) for cnidarians.

\section{Introduction}

Marine and estuarine ecosystems are influenced by a combination of physical, chemical and biological drivers that determine the structure of their communities (Reiss et al. 2015). Classic papers have reported that natural variables are the primary factors responsible for the structure of benthic communities (Ankar and Jansson 1973, Pearson and Rosenberg 1987), especially in physically controlled environments, as estuaries and other transitional waters (Tommasi 1979). Variables as salinity, temperature, dissolved oxygen, grain size, content of organic matter, among others, influence the distribution of macrobenthic organisms in coastal and estuarine waters (Grebmeier et al. 1989, Ozolin'sh 2000, Rosenberg et al. 2001). Anthropogenic factors such as pol- lution may also have an influence on benthic communities, affecting thus the species composition and distribution (Reish 1986, 1993, Pearson and Rosenberg 1987, Dauvin and Ruellet 2009, Elliott and Quitino 2007, Muniz et al. 2008, Venturini et al. 2008).

The Santos Estuarine System (SES) is located on the central coast of São Paulo state, Brazil (233' $-24^{\circ} 00^{\prime} \mathrm{S}$; $46^{\circ} 05^{\prime}$ $46^{\circ} 30^{\prime} \mathrm{W}$ ) and it was once considered one of the world's most polluted estuaries (CETESB 1985, Tommasi 1979) due to impacts of multiple contamination sources, such as the Port of Santos, the industrial complex, the unplanned urbanization, increased domestic and industrial wastes dumping, and the uncontrolled expansion of tourism. During the 1990s, an important pollution abatement program was conducted by 
the State Environmental Agency, which reduced the inputs of contaminants into the ecosystems (Lamparelli et al. 2001). However, the applied measures were not enough to restore the environmental quality of SES as demonstrated by several studies (Abessa et al. 1998, 2005, Cesar et al. 2006, Medeiros and Bícego, 2004, Martins et al. 2008, 2010, 2011, Pereira et al. 2011, 2014).

To date, sediments from the SES still present elevated concentrations of several chemicals at toxic levels for benthic organisms (Torres et al. 2009, Pereira et al. 2016, Santos et al. 2018) and some authors have shown that benthic macrofaunal assemblages are altered (Tommasi 1979, Abessa et al. 2008, Buruaem et al. 2013). These studies highlighted that pollution caused the changes, but they could not discern definitively if the alterations were due to natural factors, contaminants or a combination of both. In estuaries, disentangling the effects on benthic communities caused by natural factors from those induced by contamination is challenging because these areas are subjected to periodic variations of salinity, tides, organic matter input, currents and waves (Elliott and Quintino 2007, Dauvin and Ruellet 2009).

Integrated approaches using multiple lines of evidence (LOEs) have been recommended to deal with these challenges (Long and Chapman 1985, Burton Jr et al. 2002, Cesar et al. 2007) and they were also applied in SES. In particular, the Sediment Quality Triad (SQT) explores the relationships between sediment chemistry and laboratory-based toxicity assays with the ecological indicators of macrobenthic communities (Chapman 1990, Long et al. 2000, Burton Jr et al. 2002; Chapman and Hollert 2006, Zamboni and Abessa 2002). However, the specific composition of benthic organisms and the influence of natural factors are not considered in such methods and these data are relevant as baseline information for ecological studies and environmental management. Thus, the present study aimed to primarily characterize the macrobenthic community from the SES and evaluate the main factors responsible for its distribution along this estuarine system. We focused on identifying the roles of natural and anthropogenic factors on benthic organisms in order to fill the gaps generated in the environmental quality studies and provide information for management and conservation programs.

\section{Materials and methods}

\section{Sediment sampling}

Sediment and biological samples were collected from $20^{\text {th }}$ to $23^{\text {rd }}$ March 1998 , at 25 sampling sites distributed along the SES using a stainless steel Petersen grab sampler, with $0.026 \mathrm{~m}^{2}$ of the sampling area (Fig. 1). Sites were chosen based on the occurrence of natural gradients at Santos (St. 1 to 6) and São Vicente estuaries (St. 9 to 13), and also considering the presence of multiple contamination sources from the Industrial complex at Cubatão (St. 7 and 8) and from the sewage effluent discharges at the Santos Bay (St. 14 to 23). Two sites were located at Bertioga channel in order to cover the whole extent of the estuarine system (St. 24 and 25). Sites were georeferenced using a Garmin 38 GPS, and the geographical coordinates are shown in the supplementary material (Table S1).

For each site, the surficial $2-\mathrm{cm}$ layer of the retained sediments was collected and samples from approximately 10 replicates were pooled for the analyses of physical-chemical parameters and toxicity bioassays. Sub-samples were separated and frozen until their use for grain-size distribution, total organic carbon (TOC) and physical-chemical analyses, while another batch for toxicity tests were kept refrigerated at $4 \pm 2$ ${ }^{\circ} \mathrm{C}$ for 3-5 days. The sediment pore water was also extracted by the suction method (Winger and Lasier 1991), using 100 $\mathrm{ml}$ syringes, and then centrifuged for 20 minutes at $4200 \mathrm{~g}$
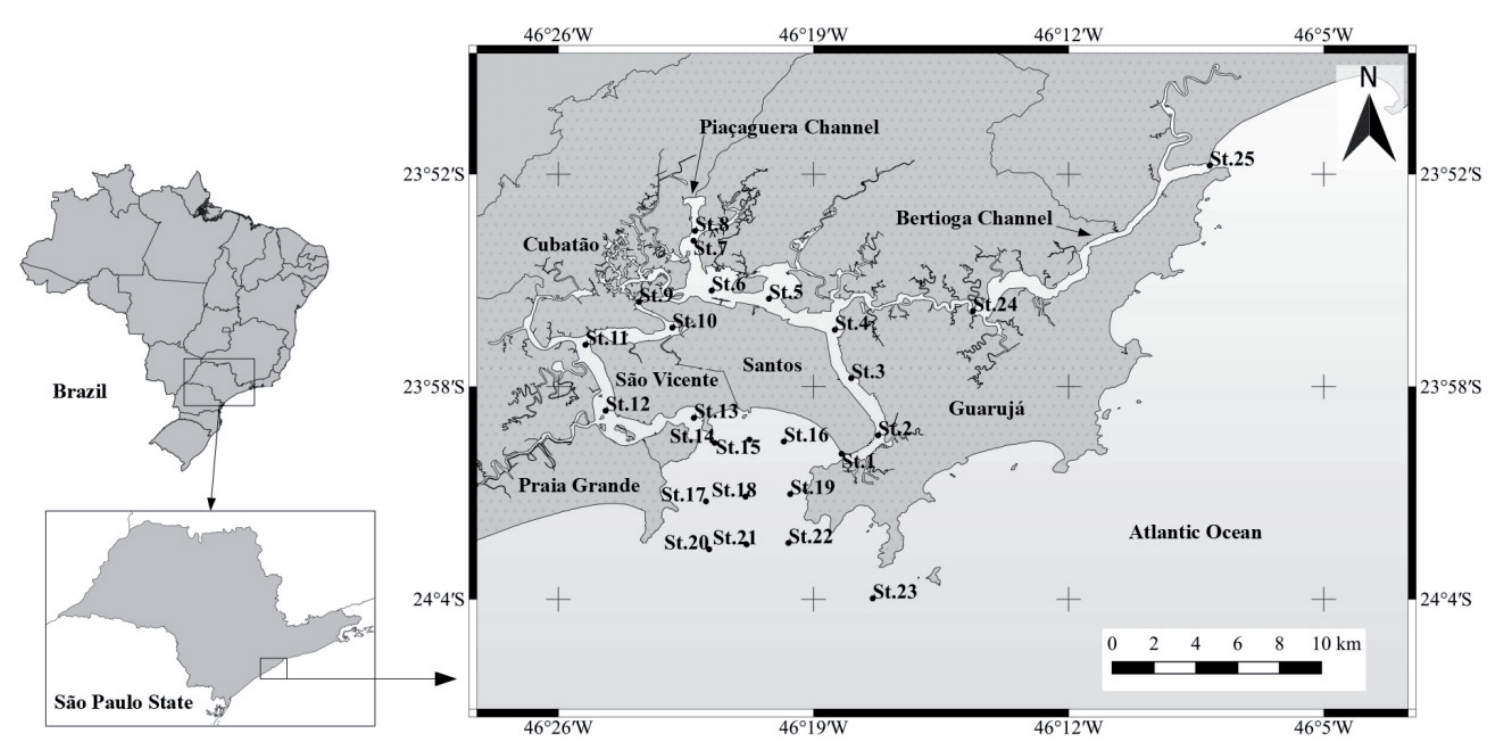

Figure 1. Map of the Santos Estuarine System - SES (SP, Brazil) showing the sampling stations. 
(Carr et al. 1996, 2000, 2001), at $4{ }^{\circ} \mathrm{C}$. The supernatant was transferred to amber glass flasks and stored frozen.

For the macrofauna, three independent replicates were obtained from the $5-10 \mathrm{~cm}$ layer of sediment. The collected material was sieved in a $0.5 \mathrm{~mm}$ mesh, and the biological material retained fixed in $4 \%$ formaldehyde for $24 \mathrm{~h}$ and then it was transferred to $70 \%$ alcohol. In each site, bottom water samples were collected using Nansen bottles (i.e., at less than 1 meter from the bottom), and their physical-chemical properties were measured in the field (See Table S2, Supplementary Material). The salinity was measured using an ATAGO-S/Mill refractometer $(0.5 \%$ precision $)$; the dissolved oxygen content was measured with a TOA oximeter (DO-14P, $0.01 \mathrm{mg} / \mathrm{L}$ precision); $\mathrm{pH}$ values were estimated by using Macherey-Nagel colorimetric indicator sticks ( 0.1 precision); and the water temperature was measured with digital thermometers $\left(0.1^{\circ} \mathrm{C}\right.$ precision $)$.

\section{Sediment properties}

The grain size distribution was analyzed by the wet sieving method to separate fine fraction (silt + clay), followed by dry sieving to separate gravel and sand fractions (Suguio 1973, McCave and Syvitski 1991). The calcium carbonate contents were estimated according to the acid digestion method (Gross, 1971), which consists of $10 \% \mathrm{HCl}$ digestion followed by the gravimetry of samples. Decarbonated sediments were analyzed for the contents of total organic carbon (TOC), nitrogen (N) and sulfur (S) using an automated analyzer model LECO CNS 2000 and the Micro Kjeldahl method (McKenzie and Wallace 1954).

The concentrations of $\mathrm{Al}, \mathrm{Fe}, \mathrm{Cd}, \mathrm{Cr}, \mathrm{Co}, \mathrm{Hg}, \mathrm{Ni}, \mathrm{Pb}$ and $\mathrm{Zn}$ were analyzed in sediment extracts. A microwaves system in high pressure was used for the total digestion of $\mathrm{Al}, \mathrm{Cr}$, and $\mathrm{Fe}$ (CEM Corporation, model MDS - 2000) in a solution composed by Milli-Q water, $\mathrm{HNO}_{3}, \mathrm{HF}$, and $\mathrm{HCl}$. For $\mathrm{Cd}, \mathrm{Co}, \mathrm{Pb}$, and $\mathrm{Zn}$, a similar procedure was employed, but using a solution of aqua regia and $\mathrm{HClO}_{4}$ in the extraction. Elements were detected using a fast sequential Atomic Absorption Spectroscope. For $\mathrm{Hg}$, samples were extracted in aqua regia and $\mathrm{HClO}_{4}$ heated for $30 \mathrm{~min}$ at $90{ }^{\circ} \mathrm{C}$ (Akagi and Nishimura 1991). The extracts were introduced into a system of Flux Injection for Cold Vapour generation (FIA-CV-AAS) (Fostier et al. 1995) and analyzed with an Atomic Absorption Spectroscope (VARIAN, AAS 220-FS).

Sediments were also analyzed for aliphatic hydrocarbons (AHs) and polycyclic aromatic hydrocarbons (PAHs), according to the protocol described by UNEP (1991). An amount of $25 \mathrm{~g}$ was Soxhlet-extracted with a $50 \%$ mixture of $\mathrm{n}$-hexane and dichloromethane for 8 hours and the extracts were fractionated into F1 (AHs) and F2 (PAHs) by silica gel-alumina column chromatography. Then, samples were eluted with n-hexane (F1) and 30\% dichloromethane in n-hexane (F2). Twenty-six AHs (n-C17 to n-C35, including pristine and phytane) were analyzed in a Gas Chromatographer (GC, Hewlett Packard, model 5890 II) equipped with the flame ionization detector maintained at $325{ }^{\circ} \mathrm{C}$ (Table S3, Supplementary
Material). Twenty-six PAHs were analyzed in a GC, coupled to a mass spectrometer in the Ion Monitoring System mode (V.G. Masslab - Fisons, model TRIO 1000) (Table S4, Supplementary Material). Concentrations were determined by the analyses of calibration curves, and the method detection limit (MDL) was calculated as 3 times the standard deviation from 7 replicates of a sample which contained surrogates. MDL values were $0.07 \mu \mathrm{g} . \mathrm{g}^{-1}$, for the total n-alkanes, and 0.24 ng. $^{-1}$ for the $\Sigma$ PAHs. The detection limits for individual compounds ranged from 0.0002 to $0.0112 \mu \mathrm{g} . \mathrm{g}^{-1}$ for n-alkanes and from 0.002 to 0.022 ng.g-1 for the $\Sigma$ PAHs.

Surfactants concentrations in sediments were estimated by the Methylene Blue Active Substance (MBAS) method (APHA/AWWA/WEF 1998) after extraction by elutriation in distilled water (Abessa and Sousa 2004). The procedure involved three successive extractions from acid aqueous medium containing methylene blue into chloroform, followed by an aqueous backwash and measurement of the blue color in the chloroform by spectrophotometry at $652 \mathrm{~nm}$. As for Quality Assurance and Quality Control procedure (QA/QC), methods for determinations were validated by the analysis of certified reference sediment Buffalo River ${ }^{\circledR}$ (for metals) and NIST (for hydrocarbons). The concentrations found for metals and PAHs were compared with Canadian sediment quality guidelines (Smith et al. 1996, Environment Canada 1999), which have been used as an environmental quality benchmark by the São Paulo State Environmental Agency (Lamparelli et al. 2001).

\section{Toxicity tests}

The whole sediment toxicity tests with the amphipod Tiburonella viscana followed the protocol described by Melo and Abessa (2002) and ABNT (2016). Sediment samples were thoroughly homogenized, and aliquots of approximately $250 \mathrm{ml}$ were introduced into the test chambers (1-L polyethylene flasks) containing $750 \mathrm{ml}$ of filtered seawater. Ten amphipods were added to each test chamber. The system was prepared in three replicates per sample and incubated for 10 days at $25 \pm 2{ }^{\circ} \mathrm{C}$, under constant aeration and light. After the exposure period, samples were sieved through a 0.5$\mathrm{mm}$ screen and the surviving amphipods were counted, with organisms considered dead. The effects induced by samples and reference sediments (control) were compared by Student t'-test (Zar 1984), and sample considered toxic when the amphipod survival was statistically lower than that exhibited by the reference group $(p<0.05)$. Levels of dissolved oxygen, salinity and $\mathrm{pH}$ of the overlying water in the test chambers were measured at the beginning and end of the test.

Toxicity of porewater samples were evaluated by the early life stage bioassay with embryos of the sea urchin Lytechinus variegatus (CETESB 1992; USEPA 1988). Prior to the test, samples were thawed at $25{ }^{\circ} \mathrm{C}$ and analyzed for salinity, $\mathrm{pH}$, dissolved oxygen and temperature. The total ammonia concentration was measured by a colorimetric method (Koroleff 1970) and the unionized ammonia levels were estimated according to Whitfield (1974) model. Adult individuals of $L$. variegatus were collected at rocky reefs in Ubatuba, 
and transported to the laboratory. The spawning was induced by the injection of $\mathrm{KCl}(0.5 \mathrm{M})$ into the celomatic cavities of the animals and the fertilization was performed in vitro. The exposure of approximately 500 embryos to the samples was initiated using glass tubes as test chamber containing $10 \mathrm{ml}$ of porewater from the samples. Four replicates were prepared for each treatment, which included 3 porewater dilutions: 100, 50 and 10\% (Carr et al. 2001). The experiment was incubated for $24 \mathrm{~h}$ at $25 \pm 2{ }^{\circ} \mathrm{C}$. After the exposure, the test was finished by the addition of $10 \%$ buffered formaldehyde into each replicate. The embryos were analyzed microscopically for morphological anomalies and retarded development (100 per replicate). The results were statistically analyzed by analysis of variance (ANOVA), followed by the Dunnett's t'test comparison using the SAS statistical package (SAS 1992).

\section{Macrobenthic community}

The biological material was identified to the lowest possible taxonomic level (i.e., to species when possible) by using identification keys, specifically for polychaetes (Day 1967, Amaral 1980, Nonato 1981, Amaral and Nonato 1982, 1984, Lana 1984, Bolívar and Lana 1986, Amaral and Nonato 1994, 1996), and mollusks (Rios 1984). Voucher samples for other groups were identified by experts. The results obtained for each sampling station were expressed as the mean number of organisms collected in a $0.026 \mathrm{~m}^{2}$. The density of individuals was expressed in ind $/ \mathrm{m}^{2}$ in order to allow comparisons to other studies. For each sampling site, the Species Richness, Shannon Diversity, Simpson Dominance, and Polychaetes Density (Magurran 1998) were estimated by using the software package Bio Diversity Professional (Lambshead et al. 1997).

Species frequency (F) was also calculated for each taxon by the following index (Guille 1970): $\mathrm{F}=(\mathrm{Pp} / \mathrm{P}) \times 100$, where: $\mathrm{Pp}$ is the number of stations where the taxon occurred and $\mathrm{P}$ is the total number of stations. Then, taxa were classified as constant $(\mathrm{Cn}$; when $\mathrm{F}>50 \%)$, common $(\mathrm{Co}$; when $10 \%<\mathrm{F}<49 \%$ ) and rare ( $\mathrm{Ra}$; when $\mathrm{F}<10 \%)$. Rare species were excluded and Bray-Curtis similarity matrices were constructed for both benthic macrofauna and environmental variables. A fourth root transformation was applied to the data to reduce the influence of abundant species. Non-metric multidimensional scaling (nMDS) ordinations were generated to investigate patterns in the structure of the macrofaunal assemblages.

\section{Data integration}

Different methods have been used to integrate complex data, as biological variables and their association to the abiotic factors (Chapman et al. 1991, Green 1993, Green and Montagna 1996). In this study we used the principal component analysis (PCA), which consisted in the simultaneous ordination of two matrices in the same multidimensional space, one containing the physical-chemical variables and the other with biological data (species densities) (Del Valls and Chapman 1998, Del Valls et al. 1998). The first matrix includ- ed variables of bottom water column $(\mathrm{pH}, \mathrm{OD}$, temperature, salinity) and sediment (depth, \% of mud, TOC, $\mathrm{CaCO}_{3}, \mathrm{~N}$, $\mathrm{S}$, metals, hydrocarbons, surfactants and toxicity data). The second matrix was constructed with the mean density values of each benthic species. Data expressed in percentages were transformed using an arcsine function and then both matrices were transformed using a logarithmic function $\log (x+1)$ in order to reduce differences in the scale of the variables. The cut-off value of $|0.50|$ for factor loading was considered as a significant correlation to a respective component (Comrey and Lee 1992), in order to show the associations between abiotic variables and species distribution.

\section{Results and discussion}

The physical and chemical parameters of water column are presented in the Supplementary Material (Table S2). The salinities of surface waters were lower in the inner parts of the estuary, while the salinities at the bottom were higher, corroborating the saline intrusion within the system (Bonetti 2000, Tommasi 1979) and also confirming the freshwater drainage from the continental basins, which flows through the surface waters (Harari et al. 2000). Water temperatures were slightly higher at the surface compared to the bottom, reflecting summer conditions in this subtropical estuary. The $\mathrm{pH}$ values were typical from marine/estuarine waters, with higher values observed at the Santos Bay and lower values reported within the estuary and close to the sewage outfall diffusers (St. 18) as reported by Rachid (2002). The dissolved oxygen levels in the bottom water ranged from 3.0 to $7.2 \mathrm{mg} \mathrm{O}_{2} / \mathrm{L}$. The lowest values occurred in the inner parts of Santos and Bertioga Channels (stations 4, 5, 6, 7, 8 and 24). Levels of dissolved oxygen were saturated with lower values reported in the inner parts of Santos and Bertioga Channels (St. 4 to 8, and 24). In general, water characteristics were consistent with descriptions of the SES provided by following studies, with continental inputs influencing the estuarine channels and marine waters acting mainly at the Bay (Bonetti 2000, Moser 2002).

The sediments of SES presented a variable composition in terms of grain-size and levels of TOC, N, and S (Table 1). Sites from Santos and Bertioga Channel exhibited muddy sediments. At São Vicente Channel, the mouth of Bertioga Channel, and west side of Santos Bay sediments were sandy. At the central and east portions of Santos Bay, which are influenced by discharges of the Santos Sewage Outfall System (SSOS) and inputs from Santos Channel, mixtures of mud and sands were found. The contents of $\mathrm{CaCO}_{3}$ were higher in the central portion of the bay and the inner part of the Santos Channel. Elevated levels of TOC, N and S occurred at high concentrations in estuarine zones and close to the SSOS outfalls at Santos Bay, along with muddy sediments, indicating the occurrence of the depositional areas, as reported in the literature (Fúlfaro and Ponçano 1976, Fúlfaro et al. 1983, Tommasi 1979, Fukumoto et al. 2004). Sedimentation rates in the Santos Channel are low, with most of the particles retained in the upper estuary with impacts of human interven- 
Table 1. Sediment grain-size and organic characteristics in the SES and reference areas.

\begin{tabular}{lrrrrrr}
\hline \multicolumn{1}{c}{ Station } & \% Sand & \% Mud & $\% \mathrm{CaCO}_{3}$ & $\mathrm{TOC}(\%)$ & $\mathrm{S}(\%)$ & $\mathrm{N}(\%)$ \\
\hline St. 1 & 14.82 & 85.18 & 11.20 & 1.39 & 0.55 & 0.12 \\
St. 2 & 6.40 & 93.60 & 21.20 & 2.53 & 0.43 & 0.27 \\
St. 3 & 0.80 & 99.20 & 21.20 & 2.37 & 0.64 & 0.22 \\
St. 4 & 29.70 & 80.73 & 23.90 & 1.03 & 0.34 & 0.09 \\
St. 5 & 2.12 & 97.88 & 20.30 & 2.14 & 0.62 & 0.16 \\
St. 6 & 8.82 & 91.18 & 11.90 & 0.79 & 0.13 & 0.07 \\
St. 7 & 11.46 & 88.54 & 11.20 & 1.39 & 0.55 & 0.12 \\
St. 8 & 56.41 & 43.59 & 14.17 & 2.76 & 0.41 & 0.27 \\
St. 9 & 60.60 & 39.40 & 11.50 & 2.62 & 0.41 & 0.11 \\
St. 10 & 93.33 & 6.77 & 12.10 & 2.03 & 0.12 & 0.09 \\
St. 11 & 91.16 & 8.84 & 11.20 & 2.51 & 0.49 & 0.08 \\
St. 12 & 98.33 & 1.77 & 6.38 & 0.31 & 0.01 & 0 \\
St. 13 & 98.34 & 1.76 & 11.33 & 1.22 & 0.02 & 0.01 \\
St. 14 & 97.03 & 2.97 & 5.20 & 0.12 & 0.01 & 0 \\
St. 15 & 95.73 & 4.27 & 6.29 & 0.14 & 0.01 & 0 \\
St. 16 & 72.74 & 27.26 & 11.33 & 0.70 & 0.13 & 0.06 \\
St. 17 & 92.17 & 7.83 & 7.43 & 0.23 & 0.03 & 0 \\
St. 18 & 28.84 & 71.16 & 21.66 & 1.39 & 1.43 & 0.12 \\
St. 19 & 33.26 & 66.74 & 17.30 & 1.55 & 0.67 & 0.14 \\
St. 20 & 97.43 & 2.57 & 5.29 & 0.14 & 0.01 & 0 \\
St. 21 & 41.97 & 58.03 & 21.27 & 1.17 & 0.55 & 0.09 \\
St. 22 & 88.03 & 11.97 & 8.35 & 0.29 & 0.04 & 0.02 \\
St. 23 & 45.53 & 54.47 & 7.70 & 0.21 & 0.03 & 0.05 \\
St. 24 & 9.82 & 90.18 & 11.30 & 0.87 & 0.09 & 0.06 \\
St. 25 & 98.74 & 1.21 & 4.73 & 0.77 & 0.05 & 0.07 \\
\hline
\end{tabular}

Sand $=$ particles $>0.0625 \mathrm{~mm}$; Mud $=$ particles $\leq 0.0625($ silts + clays $)$.

tions affecting such processes in the adjacent areas (Fúlfaro and Ponçano 1976, Fúlfaro et al. 1983).

The concentrations of metals in sediments from the SES are shown in Table 2. For most of elements analyzed, the highest concentrations tended to occur in the sediments from the inner portion of the SES. A detailed discussion of these results is presented in Abessa et al. (2008).

The higher concentrations of $\mathrm{Al}$ and Fe occurred in sediments from the upper estuary, with a decreasing gradient towards the sea. These data corroborate the results of previous studies (Bonetti 2000; Luiz-Silva et al. 2006) and also indicate inputs from industrial or terrestrial origins since a major steel plant is located at Piacaguera channel. Elevated concentrations of trace elements $\mathrm{Cd}, \mathrm{Cr}, \mathrm{Hg}, \mathrm{Ni}, \mathrm{Pb}$, and $\mathrm{Zn}$ were found above threshold values at the inner portions of Piaçaguera, Santos, and Bertioga channels (St. 4 to 9, and St. 24). The concentrations of Co were high in sediments from the upper estuary and moderate levels close to the sewage outfalls and at the West part of the Santos Bay. These levels are in accordance with other studies and can be explained by the presence of multiple sources of contamination such as port activities, the industrial complex, urban runoff and sewage releases (Prósperi et al. 1998, Lamparelli et al. 2001, Bonetti 2000, Luiz-Silva et al. 2006). Recent studies showed that the pattern of distribution reported in our study remains unchanged (Bordon et al. 2011, 2018, Kim et al. 2016, 2017). The contamination of sediments by metals is relevant in the
SES, because these chemicals are toxic, can bioaccumulate and be transferred through the trophic chain, producing ecological effects.

The results of n-alkanes, PAHs and MBAS are shown in Table 3. Details of these analyses, including the concentrations of each compound analyzed are displayed in the Supplementary Material (Tables S3 and S4) and discussed in Abessa (2002). Levels of n-alkanes occurred systematically in SES, with higher concentrations observed in estuarine zones and the SSOS vicinity, at Santos Bay (Table 3). The presence of such compounds is a proxy of AHs contamination (Medeiros and Bícego 2004). In most samples, n-alkanes were mainly from biogenic sources, according to odd/even compounds and pristane/phytane relationships, as expected in an estuarine system surrounded by mangroves (Nishigima et al. 2001). In the sediments from port and industrial areas (St. 1 to $8,10,18$ and 25), the contribution of petrogenic hydrocarbons was also relevant.

The distribution of PAHs was restricted to the Santos Channel (Table 3). The concentrations of some individual PAHs were also elevated, above threshold values (Probable Effect Levels - PELs and/or Threshold Effect Levels - TELs). A decreasing gradient toward the lower estuary was also observed, suggesting that the sources of PAHs are located in the upper estuarine portion. Our results are in accordance with the other studies (Medeiros and Bícego 2004, Bonetti 2000, Bícego et al. 2006). Concentrations reported here 
Table 2. Concentrations of metals (in $\%$ and $\mu \mathrm{g} / \mathrm{g}$ ) in sediments from the Santos Estuarine System. Numbers and italic and light-grey cells indicate values above the TEL; numbers in bold and dark-grey cells indicate values above the PEL.

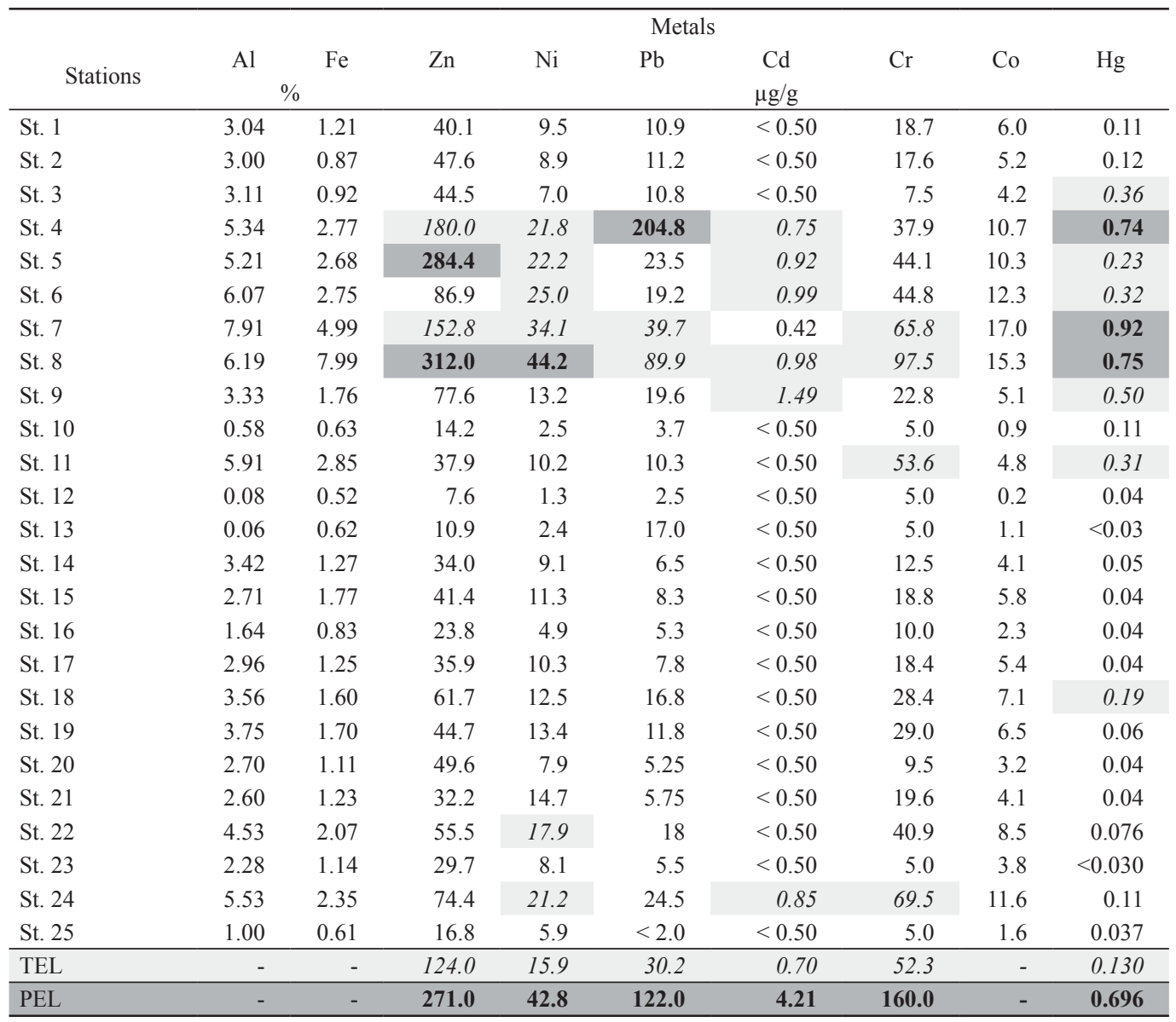

were higher than those found in São Sebastião (Weber et al. 1998) and similar to those reported to the Montevideo Harbor (Muniz et al. 2004) and Todos os Santos Bay (Venturini and Tommasi 2004). Levels of detergents (MBAS) were detected close to the SSOS diffusers, followed by the stations from São Vicente channel, corroborating the ranges observed by Tommasi (1979).

Results of whole sediment toxicity to $\mathrm{T}$. viscana are presented in the Fig. 2. The samples from the estuarine channels (St. 1 to 10,24 and 25) were considered toxic, as well as those from the stations 17 and 18, located close to the SSOS diffusers (St. 17 and 18) (Figure 2). The physical-chemical parameters of the overlying water within the test-chambers were considered suitable for $T$. viscana (Supplementary Material, Table S5). The results of the porewater toxicity test are shown in the Figure 3 and in Supplementary Materials (Tables S6 and S7). Samples from stations 20 and 25 were not tested. All the porewater samples were toxic and produced significant reduction of the larval development (excepting the St. 17 at $50 \%$ ). The toxicity persisted in samples at $25 \%$ porewater dilution, with exception of the samples from the St. 10 , 15, 16, 17 and 21. The unionized ammonia can contribute to the toxicity in porewater samples (Carr et al. 2001), and the no effective concentration (NOEC) of $\mathrm{NH}_{3}$ for L. variegatus embryonic development is $0.05 \mathrm{mg} / \mathrm{L}$ (Prósperi 2002). In this investigation, the toxicity occurred even when the $\mathrm{NH}_{3}$ levels were low, suggesting that other contaminants were probably responsible for the toxicity. Some recent publications reported that ammonia is an important contaminant to the SES and is capable of interacting with other substances, increasing the toxic effects to benthic organisms (Araújo et al. 2013, Camargo et al. 2015, Moreira et al. 2019). A qualitative interpretation of the ammonia influence on the porewater toxicity is presented on the Supplementary Material (Table S7).

The stations from the estuarine zones and the SSOS vicinities were the most toxic. Despite the influence of contaminants released by port and industrial activities, recent studies also showed that the vicinities of the SSOS present contamination by contaminants of emerging concern (CECs), such as phenols, hormones, fecal sterols, pharmaceutical and personal care products, drugs of abuse, and others (Santos et al. 2018, Pereira et al. 2016). Our results are in agreement with previous studies carried out in the SES (Abessa et al. 2001, 2005, Abessa and Sousa 2001), and after our sampling campaing, other studies corroborated our findings (Sousa et al. 2007, Cesar et al. 2006, Rachid, 2002, Prósperi et al. 1998, Araújo et al. 2013, Buruaem et al. 2013, Moreira et al. 2019).

For macrobenthic community a total of 1,413 individuals were collected in SES. The raw data for benthos is available in the Supplementary Material (Table S8) and a detailed 


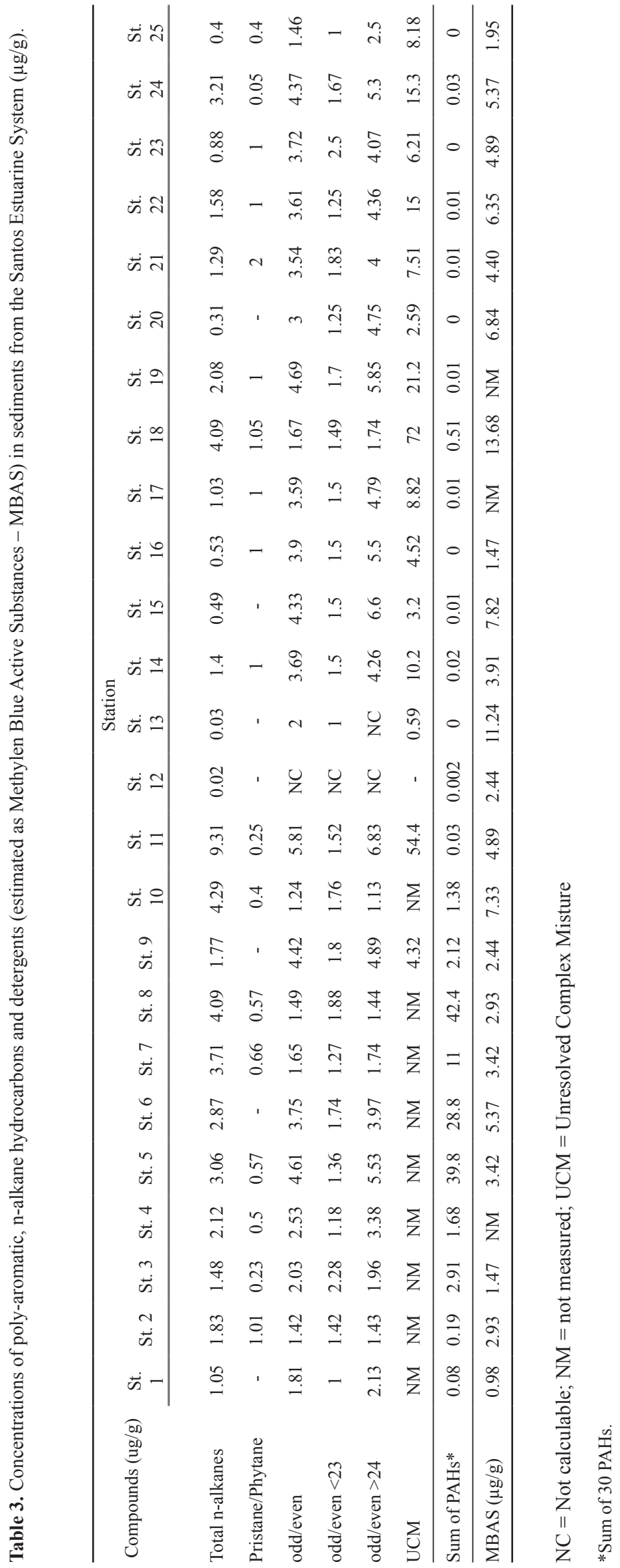




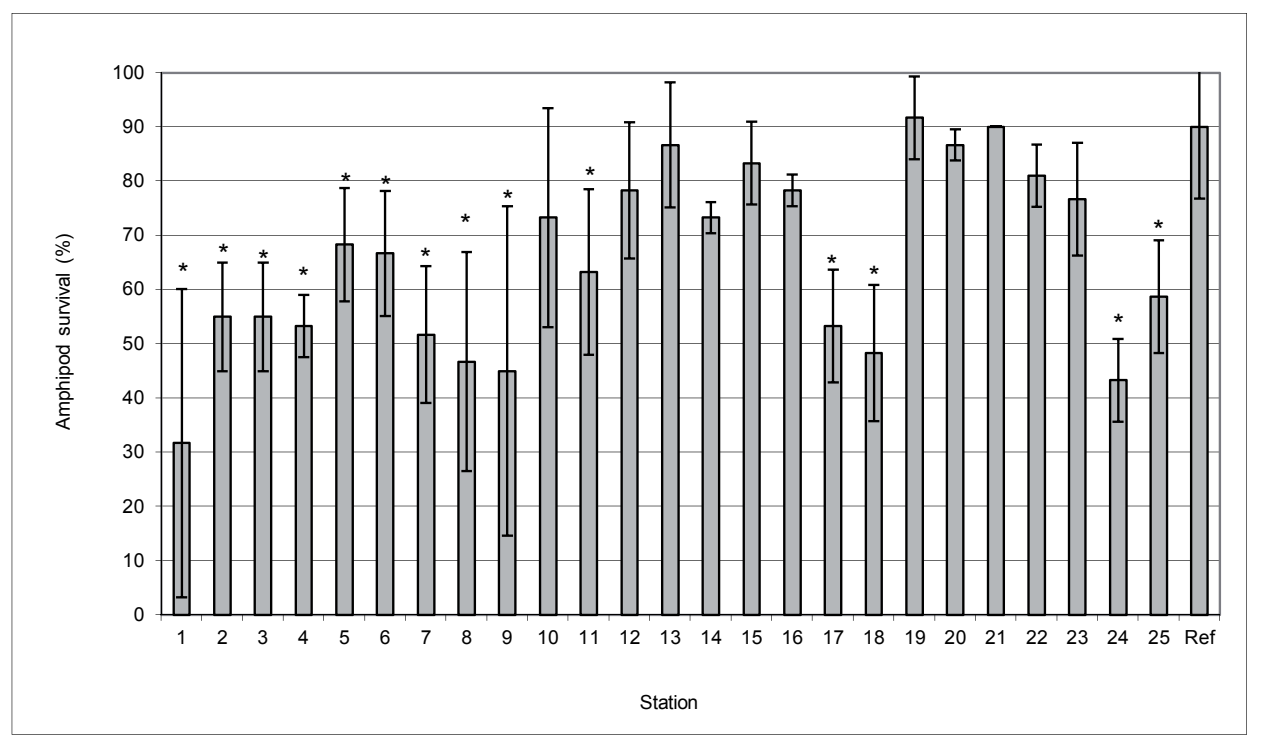

Figure 2. Whole sediment toxicity to the amphipod T. viscana, $(*=$ significant difference $(\mathrm{p}<0.05)$.

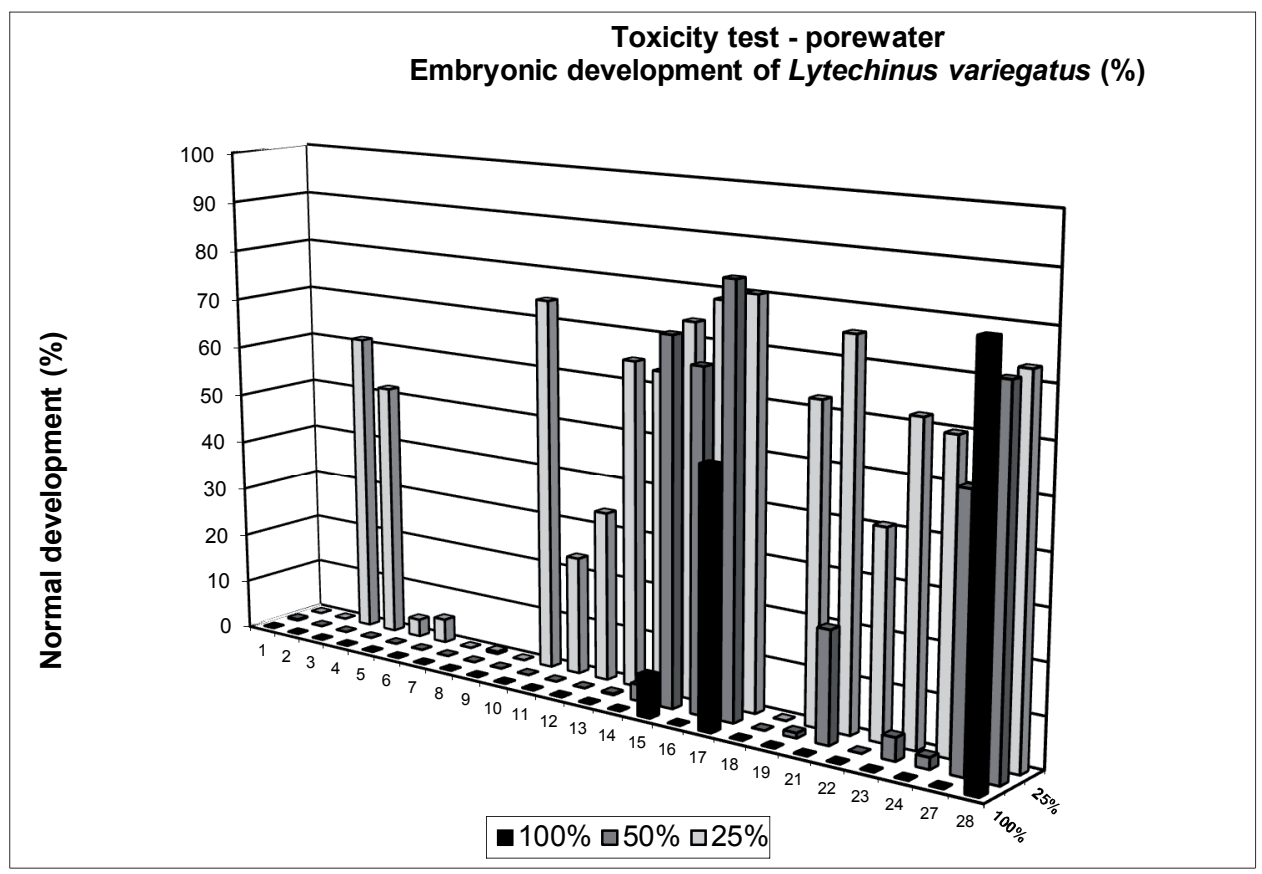

Figure 3. Mean normal embryonic development of Lytechinus variegatus exposed to pore water extracted from sediments from the Santos Estuarine System.

analysis including a "station by station" approach was provided in Abessa (2002). Samples exhibited few species, with predominance of polychaetes, followed by bivalve mollusks. The dominance of polychaetes was above $60 \%$, whereas crustaceans occurred only at the stations 1, 13, 17 and 19. About 56 taxa of polychaetes were identified, 18 bivalves, 6 gastropods, 11 crustaceans, 2 ophiuroids, among others (see Table 4 for the list of species identified). The St. 16 presented the higher number of species (37 in total) and St. 22 exhibited the highest abundance, estimated in 10,564 individuals per $\mathrm{m}^{2}$. Abundance was also higher at ST. 1, 16, 23, 24, and 25. No organisms were found at St. 5 and 12, and low abundances were estimated at St. 4, 8, 10, 13, 14, 15, 17 and $20(<100$ indiv. $\left./ \mathrm{m}^{2}\right)$.

Most of the species found were considered rare, occurring at only one, two or three stations. The more common taxa were polychaetes, especially Capitella capitata and Owenia fusiformis. Other common taxa included the polychaetes Rhodine sp., Magelona posterolongata, Ninoe brasiliensis, Ophioglycera sp, Hemipodus sp., Nephtys sp., Lumbrineris sp. and Diopatra cuprea, the mollusks Anachis obesa (gastropod), Chione cancelata, Tagellus sp. and Ctena pectinella 
Table 4. List of macrobenthic species identified in the Santos Estuarine System.

\begin{tabular}{|c|c|c|}
\hline \multicolumn{3}{|c|}{ Taxa } \\
\hline Polychaeta & Polychaeta & Penaeidae \\
\hline Rhodine sp & Spiophanes sp & Trachypenaeus constrictus \\
\hline Magelona posterelongata & Eunice (sensu stricto) & Thalassinidea \\
\hline Goniadidae (unidentified) & Marphysa sp & Upogebia affinis \\
\hline Glycinde $s p$ & Lysidice $s p$ & Paguroidea \\
\hline Goniadides $s p$ & Paraeulepis sp & Clibanarius vitatus \\
\hline Goniada sp & Cirrophorus sp & Brachyura \\
\hline Ophioglycera sp & Paraonis sp & Tetraxanthus rathbunae \\
\hline Glyceridae (unidentified) & Euphrosine sp & Cyrtoplax spinidentata \\
\hline Hemipodus sp & Hesionidae (unidentified) & Amphipoda \\
\hline Glycera sp & Pilargidae (unidentified) & Tiburonella viscana \\
\hline Euzonus (Thoracophelia) & Phylodocidae (unidentified) & Photis longicaudata \\
\hline Nephtydae (unidentified) & Sabellidae (unidentified) & Isopoda \\
\hline Nephtys sp. & Gastropoda & Excirollana armata \\
\hline Capitelidae (unidentified) & Heleobia australis & Tanaidacea \\
\hline Mediomastus sp. & Calyptrea centralis & Kalliapseudes schubartii \\
\hline Heteromastus filiformis & Nassarius vibex & Mysidacea \\
\hline Capitella capitata & Turbonilla nivea & Promysis atlantica \\
\hline Dasybranchus sp & Anachis sertulariarum & Dendrobranchiata (n.i.) \\
\hline Terebellidae (prob. Pista sp.) & Anachis obesa & Teleostei \\
\hline Trichobranchus sp & Nudibranchia & Ribeiroclinus eigenmanni \\
\hline Scoloplos (Leodamas) sp & Doris bovena & Anthozoa \\
\hline Haploscoloplos sp & Etidoris ladislavii & Renila \\
\hline Laeonereis acuta & Bivalvia & Edwardsia sp \\
\hline Nereidae (unidentified) & Tellina $\mathrm{sp}$ & Ophiuroidea \\
\hline Naineris setosa & Tellina alternata & Microphiopholis atra \\
\hline Prob. Pseudeurythoe & Semele sp1 & Ophionereis reticulata \\
\hline Pectinaria $s p$ & Semele purpurascens & Nemertina (unidentified) \\
\hline Dorvilleidae (unidentified) & Ctena pectinella & \\
\hline Syllidae (unidentified) & Felaniella candeana & \\
\hline Typosilis $s p$ & Periplona ovata & \\
\hline Ninoe brasiliensis & Chione cancelata & \\
\hline Lumbrineris $s p$ & Crassinela martinicensis & \\
\hline Serpulidae (unidentified) & Tagellus sp & \\
\hline Owenia fusiformis & Mactra fragilis & \\
\hline Onuphidae (unidentified) & Corbula patagonica & \\
\hline Nothria & Strigilla carnaria & \\
\hline Rhamphobrachium sp. & Laevicardium brasilianum & \\
\hline Americonuphis & Ervilia $\mathrm{sp} 2$ & \\
\hline Diopatra cuprea & Tivella mactroides & \\
\hline Chaetopteridae (unidentified) & Abra lioica & \\
\hline Mesochaetopterus sp & Anomalocardia brasiliana & \\
\hline Poecilochaetus sp & & \\
\hline Scolelepis $s p$ & & \\
\hline Laonice sp. & & \\
\hline
\end{tabular}

(bivalves), and the ophiuroid Microphiopholis atra. Most of these species are typically from coastal marine regions or cosmopolitan, except for Anachis obesa, which is found in estuarine areas. Among these species, C. capitata, O. fusiformis, M. posterolongata, and Nephtys sp. are considered pollution tolerant, suggesting that the contamination influences on the benthic species composition. In general, the species richness was low, as expected for complex estuarine systems that are subject to extreme natural environmental variations and gradients (Table 5). Species richness was higher at stations lo- cated on the east side of Santos Bay (St. 16, 19, 22 and 23), in the mouth of Santos Channel (St. 1 and 2) and in Bertioga Channel (St. 24). In Santos Bay, the west portion tended to exhibit few species (stations 14, 17 and 20) compared to the east side (St. 16, 19, 22 and 23).

Such pattern had been described previously by Tommasi (1979), but the specific composition of assemblages differed from those observed in the present study. A further study conducted by Moreira et al. (2019) confirmed the trends ob- 
Table 5. Ecological Indices (Specific Richness; Simpson Dominance, Shannon Diversity (H') and polychaete abundances, in each sampling station.

\begin{tabular}{|c|c|c|c|c|}
\hline \multirow{3}{*}{ Station } & \multicolumn{4}{|c|}{ Ecological Indices } \\
\hline & Specific & Diversity & Simpson & Polychaetes \\
\hline & Richness & Shannon & dominance & abundance (\%) \\
\hline St. 1 & 16 & 1.611 & 0.399 & 58.54 \\
\hline St. 2 & 15 & 2.380 & 0.134 & 37.93 \\
\hline St. 3 & 9 & 1.942 & 0.257 & 80.00 \\
\hline St. 4 & 1 & 0 & 1.000 & 0 \\
\hline St. 5 & 0 & 0 & $\mathrm{nc}$ & 0 \\
\hline St. 6 & 5 & 1.560 & 0.211 & 75.00 \\
\hline St. 7 & 10 & 1.033 & 0.610 & 94.91 \\
\hline St. 8 & 4 & 1.330 & 0.268 & 83.33 \\
\hline St. 9 & 3 & 0.656 & 0.641 & 100 \\
\hline St. 10 & 2 & 0.693 & 0.480 & 100 \\
\hline St. 11 & 8 & 1.774 & 0.204 & 92.86 \\
\hline St. 12 & 0 & 0 & $\mathrm{nc}$ & $\mathrm{nc}$ \\
\hline St. 13 & 1 & 0 & 1.000 & 0 \\
\hline St. 14 & 3 & 1.099 & 0.316 & 66.67 \\
\hline St. 15 & 4 & 1.332 & 0.269 & 80.00 \\
\hline St. 16 & 37 & 3.362 & 0.047 & 50.77 \\
\hline St. 17 & 3 & 1.040 & 0.363 & 0 \\
\hline St. 18 & 6 & 0.911 & 0.560 & 91.30 \\
\hline St. 19 & 14 & 2.432 & 0.104 & 88.00 \\
\hline St. 20 & 2 & 0.693 & 0.480 & 50.00 \\
\hline St. 21 & 9 & 1.946 & 0.190 & 85.71 \\
\hline St. 22 & 18 & 0.815 & 0.673 & 99.16 \\
\hline St. 23 & 18 & 2.642 & 0.088 & 85.71 \\
\hline St. 24 & 17 & 2.383 & 0.127 & 83.05 \\
\hline St. 25 & 13 & 2.108 & 0.154 & 97.32 \\
\hline
\end{tabular}

$\mathrm{nc}=$ not calculable

served at the west of Santos Bay, with dominance of polychaetes (Cirratulidae and Capitellidae) and presence of sensitive organisms such as amphipods. The pattern exhibited by Shannon diversity (H') was similar to species richness and values were low compared to a previously investigation (Tommasi, 1979), which can be attributed to differences in sampling strategy. The occurrence of few individuals and rare species in the majority of stations resulted in low values of Simpson dominance. The elevated dominance of polychaetes is also an indicator of altered communities typically found in naturally stressed environments as in the case of estuarine systems (Reish 1986, Van Dolah et al. 1999, Weisberg et al. 1997). The SES is a physically controlled environment, known to be complex and dynamic, where the abiotic variables are more important than interspecific relationships as controlling factors of benthic communities structures (Tommasi 1979). In this situation, the opportunistic organisms (r-strategists) are favored, as demonstrated by the opportunistic species, such as Capitella capitata, Magelona posterolongata, Owenia fusiformis, Rhodine sp, Anachis obesa, and Chione cancelata.

The use of nMDS analysis aimed to explore the influence of abiotic factors on the benthic fauna and the results for environmental variables (Fig. 4) showed that stations from Santos estuary towards Piaçaguera Channel (St. 1 to 9), were dissimilar from the other stations, including Bertioga channel (St. 24, and 25), São Vicente estuary (St. 10-13) and Santos Bay (St. 14 to 23). On the other hand, such a pattern was not apparent in the structure of assemblages. However, there was a trend showing that some samples from Santos estuary (St 1, 3, 4, 6, 7 and 9) separated from the other stations in a similar manner, indicating a possible combination of multiple variables in the distribution of the species. The influence of natural stressors makes it difficult to discern the effects of contaminants on the benthic community structure of the SES. In disturbed sites, the disappearance of sensitive species followed by the dominance of resistant organisms (Gesteira and Dauvin 2000) is described in the literature as well the occurrence of lower densities and fewer species (Dumbauld et al. 2001, Lardicci et al. 2001).

Studies on benthic community ecology have proposed the concept of estuarine quality paradox (Elliott and Quintino 2007, Dauvin and Ruellet 2009), which demonstrates the challenge to detect the effects of anthropic factors on ecological status due to the variety of conditions that can occur in an estuary as a result of natural stressors. The benthic community structure found in our study followed the pattern described by Tommasi (1979), where the estuarine system was separated from the east and the west portions (including bay). 

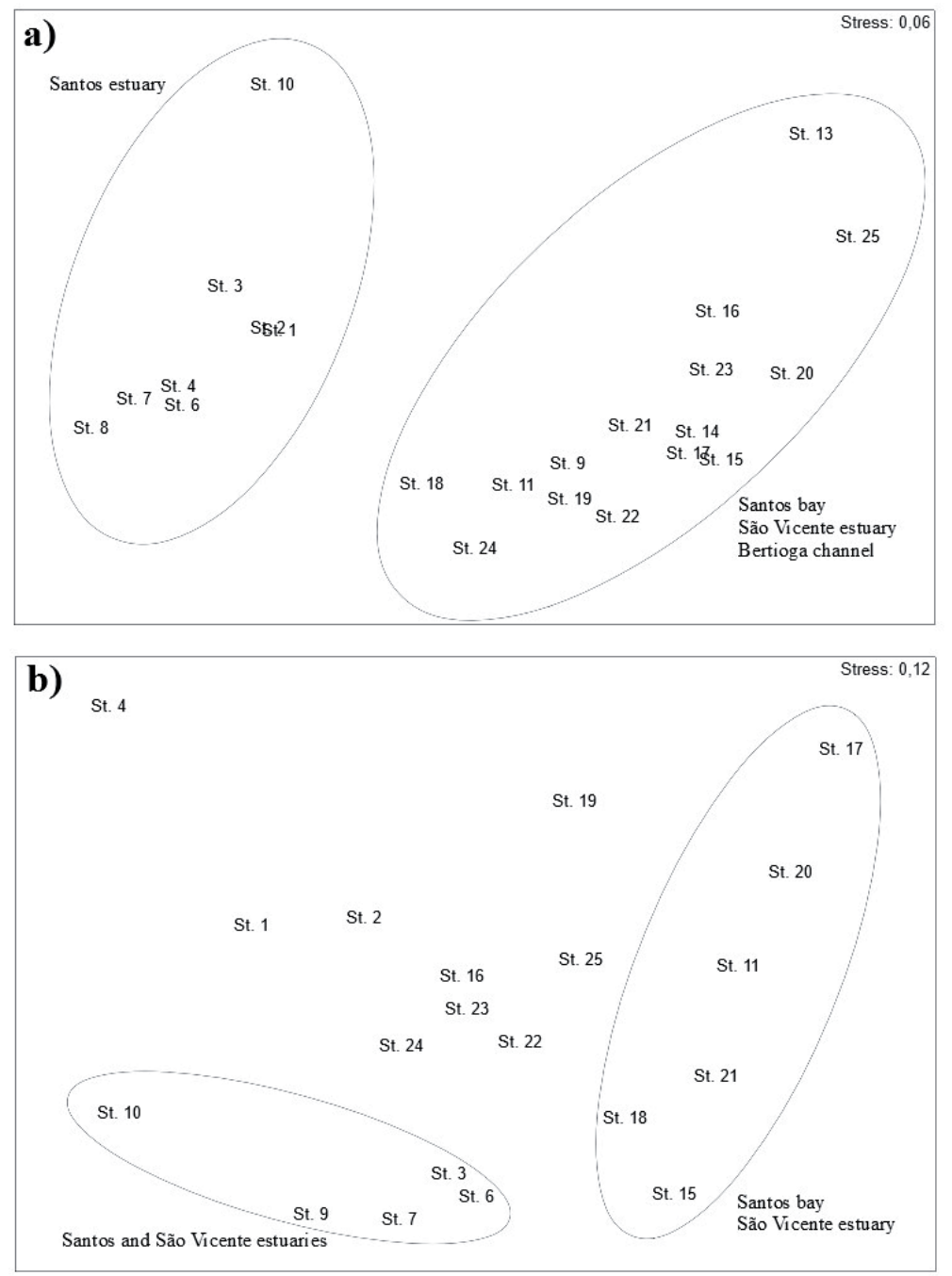

Figure 4. Ordination of samples based on nMDS results of environmental variables (a) and benthic community composition (b).

The author also pointed out that the existence of physiological stress gradients from the bay towards the estuary and in this case, such gradients were relevant for the most impacted sites (St 4 to 12). The convergence of both gradients of contamination and natural stressors in SES is an example of how the complexity of disturbances described on the estuarine quality paradox is relevant to describe benthic assemblages.

\section{Data integration}

To understand the influence of the natural stressors on the benthic community structure is a relevant issue and to explore that, both natural and anthropic factors were integrated with benthic fauna data, because we hypothesized that the combination of both is conditioning the structure of the communities in the SES. The first three components (PCs) of the PCA explained $68.51 \%$ variances (see Fig. 5 and Tables S9 to S12 in the Supplementary Material). The PC-1 represented $46.94 \%$ variances and accounted for positive correlations of water physical-chemical variables (temperature, $\mathrm{pH}, \mathrm{OD}$ and salinity) and negative for the most of contaminants (excepting MBAS) and sediment toxicity. Among species, Semele purpurascens correlated positively to the axis 1, while Trichobranchus sp., Naineris setosa., (Prob) Pseudoerythoe sp., Pectinaria sp., Tetraxanthus rathbunae, and Kalliapseudes schubartii presented negative correlations. These results suggest that species negatively correlated to the PC-1 were tolerant and/or favored by contamination, specifically at Santos Channel estuary (St. 1 to 9), São Vicente Channel (St. 11), SSOS diffusers (St. 18) and the inner portion of Bertioga Channel (St 24).

The PC-2 represented $14.27 \%$ of variances, with positive correlations found for temperature and $\mathrm{Fe}$, and negative correlations reported for mud, $\mathrm{CaCO}_{3}, \mathrm{TOC}, \mathrm{N}$ and $\mathrm{S}$, which characterizes the organic enrichment and the depositional areas. No species correlated positively to the PC-2, but Marphysa sp., Glycera sp.; Terebellidae (probably Pista sp.), Ctena pectinella, Chione cancelata, Corbula patagonica and Tagellus sp. were negatively correlated and they seem to be adapted to the such conditions, specifically at estuarine sites (St. 1 to \#4, 9 and 10) and close to SSOS diffusers (St. 16, 18, 19 and 21). The PC-3 accounted for $7.296 \%$ variances and 


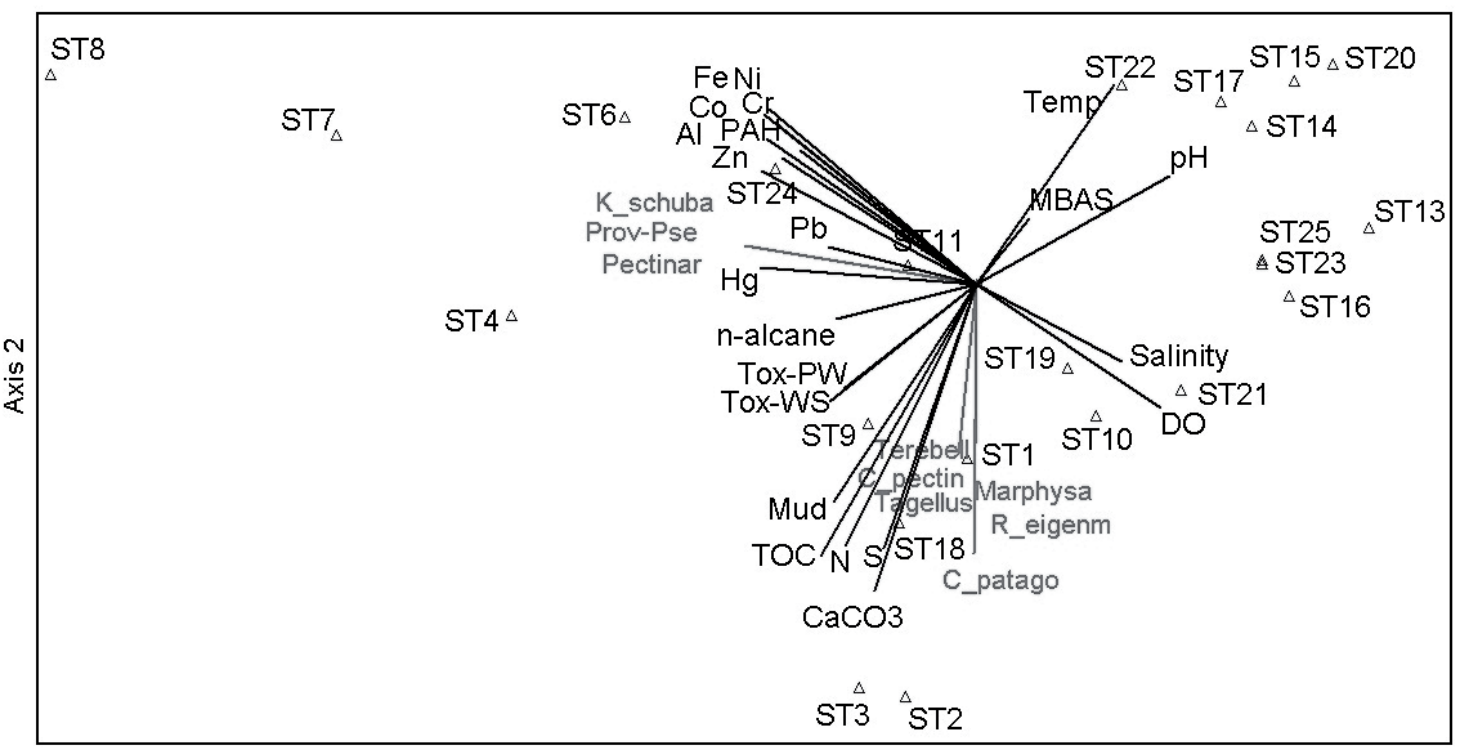

Axis 1

Figure 5. Results of the Principal Component Analysis ordination using data of geochemistry, toxicity, and benthic community obtained at the Santos Estuarine System.

presented positive correlations for n-alkanes and negative for temperature, S and MBAS. The polychaete Magelona posterolongata presented positive correlation to this $\mathrm{PC}$, whereas the bivalve Felaniella candeana was negatively correlated.

The bi-dimensional ordination of axis 1 and 2 clustered one group composed by sites which exhibited organic enrichment, toxicity, and the presence of opportunistic species such as Tagellus sp. and C. patagonia (St.1, 2, 3, 9 and 18). The second group included sites within the Santos and Bertioga channels (St. 4, 6, 7, 8, 11 and 24), which sediments were contaminated by metals, n-alkanes, and PAHs; these sites also presented the occurrence of tolerant species such as $K$. schubartii, Pseudoerythoe sp. and Pectinaria sp. A third group separated low contaminated sites, located in the mouth of São Vicente and Bertioga channels (St 13 and 25, respectively), and Santos Bay (stations 14 to 17, 20, 22, and 23). The fourth group gathered stations influenced by marine conditions at Santos bay (St. 19 and 21) and a low number of organisms at São Vicente Channel (St 10) (Fig. 5).

The moderated amount of variance explained by the PCA reflects the heterogeneity of the studied environment, and indicates that other stressors may also influence the benthic composition of SES. Another issue is the elevated number of rare species, which resulted in a matrix composed of absent data. Other study carried out in Biscayne Bay, Florida, found a similar result of multivariate methods due to the complexity of conditions (Long et al. 2002). Van Dolah et al. (1999) pointed out that responses of benthic communities may be influenced by confounding factors, such as the number of absent species, making thus the integration of biological data with variables quite difficult. The alternative of using ecological indices may be also low efficient to detect environmental disturbances in these situations (Borja et al. 2000, Drake et al. 1999, Eaton 2001).
In summary, benthic assemblages were affected in sites from the inner portions of the SES and vicinities of the SSOS diffusers as Santos Bay (St 3 to 10, 18 and 24), which was supported by chemical contamination and sediment toxicity. Six stations exhibited moderately condition of disturbance (St. 1, 2, 11, 13, 22 and 17). In the stations St.1 and 2, the macrobenthic community was rich and diverse, and the concentrations of measured contaminants were low, but sediments were toxic. Other sites from the mouth of São Vicente and Bertioga channels (St. 14 and 25), and Santos Bay (St. $15,16,19,20,21$, and 23) benthic fauna were considered not degraded. Recent studies conducted in this region produced similar results considering only ecological indices, but not the species composition (Buruaem et al. 2013; 2015). Thus, our results complement those findings by providing baseline information on the fauna composition at the time in different sectors of SES.

\section{Conclusions}

In this study, we described the existence of natural and anthropogenic stressors (i.e., grain size, contamination, and toxicity) in SES gradients that influence the structure of benthic communities. Benthic communities were more disturbed in sites influenced by contamination sources, as those listed by the Sao Paulo State Environmental Agency - CETESB (Lamparelli et al. 2001). The most critical area was the inner portion of Santos Channel (Piaçaguera Channel), due to the presence of an industrial complex. In the São Vicente Channel, despite the moderate contamination, the benthic community was also affected. In the Santos Bay, where natural factors seem to be more important in shaping the structure of communities, sites influenced by the SSOS were enriched in contaminants and organic materials, having additional effects on benthic organisms. The integration approach applied 
in our study revealed that both natural and anthropogenic factors influenced the structure of benthic communities. The complexity of SES represents a challenge to evaluate its environmental quality status.

Acknowledgements: We would like to thank FAPESP (98/00808-6 Process) and PROPe-UNESP (Process 0067/017/13-PROPe/CDC) for the financial support; the IOUSP North Base staff for the logistic and general assistance; and the help of Professor L. Roberto Tommasi, Dr. F. Attolini, Professor E. Nonato (in memoriam), Dr. K. Christol dos Santos, Dr. M. T. Valério Belardo, Dr. M. F. Lopes dos Santos, Dr. A. M. Setúbal Pires Vanin and Dr. T. Navajas Corbisier, who kindly identified some taxonomic groups (respectively, echinoderms, polychaetes, tanaids, amphipods, cumaceans, isopods and anthozoans). We greatly appreciate the constructive technical reviews provided by Drs. M. Nipper, S. Carr and E. Long. D. Abessa also thanks CNPq by the PQ fellowship (Grants \#303620/2008-0; \#311609/20147). L.B. Moreira also thanks FAPESP (grant number 2013/15482-0).

\section{References}

Abessa, D.M.S. 2002. Avaliação da qualidade de sedimentos do Sistema Estuarino de Santos. Doctorate Thesis. Universidade de São Paulo, Instituto Oceanográfico.

Abessa, D.M.S. and E.C.P.M. Sousa. 2001. Preliminary studies on the acute toxicity of marine sediments collected close to the sewage outfalls from Baixada Santista, SP, Brazil. In: Proceedings of the $1^{\circ}$ Congresso Brasileiro de Pesquisas Ambientais. September, 2001. Santos, SP, Brazil. CD-Rom, pp. 59-61.

Abessa, D.M.S. and E.C.P.M. Sousa. 2004. Adaptação de método de extração de tensoativos aniônicos de sedimentos hídricos marinhos para análise por MBAS: aplicação em avaliações ambientais preliminares. Mundo Saúde 28(4):431-435.

Abessa, D.M.S., R.S. Imai and J. Harari. 2008. Toxicidade da Água na Baía de Santos. In: Braga, E.S. (ed.), Oceanografia e Mudanças Globais. USP, São Paulo, pp. 659-668.

Abessa, D.M.S., E.C.P.M. Sousa, B.R.F. Rachid and R.R. Mastroti. 1998. Use of the burrowing amphipod Tiburonella viscana as tool in marine sediments contamination assessment. Braz. Arch. Biol. Techn. 41(2):225-230.

Abessa, D.M.S., E.C.P.M. Sousa, B.R.F. Rachid and R.R. Mastroti. 2001. Sediment toxicity in Santos Estuary, SP-Brazil: preliminary results. Ecotox. Environ. Restoration 4(1):6-9.

Abessa, D.M.S., R.S. Carr, B.R.F. Rachid, E.C.P.M. Sousa, M.A. Hortelani and J.E. Sarkis. 2005. Influence of a Brazilian sewage outfall on the toxicity and contamination of adjacent sediments. Mar. Pollut. Bull. 50:875-885.

ABNT - Associação Brasileira de Normas Técnicas. 2016. Ecotoxicologia aquática - Toxicidade aguda - Método de ensaio com anfipodos marinhos e estuarinos em sedimentos. ABNT. Norma Técnica NBR 15638, Rio de Janeiro, RJ.

Akagi, H. and H. Nishimura. 1991. Speciation of mercury in the environment. In: Suzuki, T., Imura, N. and Clarkson, T.W. (eds.), Advances in Mercury Toxicology, Plenum Press, New York. pp. $53-76$

Amaral, A.C.Z. 1980. Breve caracterização dos gêneros da família Capitellidae Grube (Annelida Polychaeta) e descrição de
Nonatus longilineus Ge. Sp. N. Bolm. Inst. Oceanogr. S Paulo, 29(1):99-106.

Amaral, A.C.Z. and E.F. Nonato. 1982. Anelídeos poliquetos da costa brasileira. 3 - Aphroditidae e Polynoidae. Brasília, Brazil. $\mathrm{CNPq} / \mathrm{Coordenação} \mathrm{Editorial.}$

Amaral, A.C.Z. and E.F. Nonato. 1984. Anelideos poliquetos da costa brasileira. 4 - Polyodontidae, Pholoidae, Sigalionidae e Eulepethidae. Brasília, Brazil. CNPq/Coordenação Editorial.

Amaral, A.C.Z. and E.F. Nonato. 1994. Anelídeos poliquetos da costa brasileira. 5 - Pisionidade, Chrysopitellidae, Amphinomidae e Euphrosinidae. Rev. Bras. Zool. 11(2):361-390.

Amaral, A.C.Z. and E.F. Nonato. 1996. Annelida Polychaeta: Características, glossário e chaves para famílias e gêneros da costa brasileira. Editora da Unicamp. Campinas, SP, Brazil. 1240 .

Ankar, S. and B.O. Jansson. 1973. Effects of an unusual natural temperature increase on a Baltic soft bottom community. Mar. Biol. 18:9-18.

APHA/AWWA/WEF. 1998. 5540 - Surfactants. In: American Public Health Association, Water Environment Federation. Standard Methods for Examination of Water and Wastewater. 20th ed., USA. 1269 p.

Araujo, G.S., L.B. Moreira, R.D. Morais, M.B. Davanso, T.F. Garcia, A.C.F. Cruz and D.M.S. Abessa. 2013. Ecotoxicological assessment of sediments from an urban marine protected area (XixováJapuí State Park, SP, Brazil). Mar. Pollut. Bull. 75(1-2):62-68.

Bícego, M.C., S. Taniguchi, G.T. Yogui, R.C. Montone, D.A.M. Silva, R.A. Lourenço, C.C. Martins, S.T. Sasaki, V.H. Pellizari and R.R. Weber. 2006. Assessment of contamination by polychlorinated biphenyls and aliphatic and aromatic hydrocarbons in sediments of the Santos and São Vicente Estuary System, São Paulo, Brazil. Mar. Pollut. Bull., 52:1784-1832.

Bolívar, G.A. and P.C. Lana. 1986. Padrões de distribuição de Spionidae e Magelonidae (Annelida: Polychaeta) do litoral do Estado do Paraná. Master of Science Dissertation. Universidade Federal do Paraná.

Bonetti, C. 2000. Foraminiferos como bioindicadores do gradiente de estresse ecológico em ambientes costeiros poluídos. Estudo aplicado ao sistema estuarino de Santos - São Vicente (SP, Brasil). Doctorate Thesys. Universidade de São Paulo, Instituto Oceanográfico. São Paulo.

Bordon, I.C.A.C., J.E.S. Sarkis, G.M. Gobbato, M.A. Hortellani, and C.M. Peixoto. 2011. Metal Concentration in Sediments from the Santos Estuarine System: a Recent Assessment. J. Braz. Chem. Soc. 22(10): 1858-1865.

Bordon, I.C.A.C., J.E.S. Sarkis, N.P. Andrade, M.A. Hortellani, D.T. Favaro, M.H. Kakazu, M.E.B. Cotrim, R.T. Lavradas, I. Moreira, T.D. Saint'Pierre and R.A. Hauser-Davis. 2018. An environmental forensic approach for tropical estuaries based on metal bioaccumulation in tissues of Callinectes danae. Ecotoxicology 25:91-104

Borges, M., A.M.G. Monteiro and A.C.Z. Amaral. 2002. Taxonomy of Ophiuroidea (Echinonermata) from the continental shelf and slope of the southern and southeastern Brazilian coast. Biota Neotrop. 2(2):1-69.

Borja, A., J. FRANCO and V. PÉREZ. 2000. A marine biotic index to establish the ecological quality of soft-bottom benthos within European estuarine and coastal environments. Mar. Pollut. Bull. 40(12):1100-1114

Burton Jr., G.A.. G.E. Batley, P.M. Chapman, V.E. Forbes, E.P. Smith, T. Reynoldson, C.E. Schlekat, P.J. den Besten, A.J. Bailer, A.S. Gree and R.L. Dwyer. 2002. A weight-of-evidence framework for assessing sediment (or other) contamination: improving cer- 
tainty in the decision-making process. Hum. Ecol. Risk Assess. 8:1675-1696

Buruaem, L.M, I.B. Castro, M.A. Hortellani, S. Taniguchi, G. Fillmann, S.T. Sasaki, M.A.V. Petti, J.E. Sarkis, M.C. Bícego, L.A. Maranho, M.B. Davanso, E.F. Nonato, A. Cesar, L.V. Costa-Lotufo and D.M.S. Abessa. 2013. Integrated quality assessment of sediments from harbour areas in Santos-São Vicente Estuarine System, Southern Brazil. Estuar. Coast. Shelf. Sci. 130, 179-189.

Buruaem, L.M., M.A.V. Petti, and D.M.S. Abessa. 2015. Soft-bottom polychaetes from the Brazilian harbors of Mucuripe and Pecém (State of Ceará) and Santos (State of São Paulo). Checklist 11(4):1721. http://dx.doi.org/10.15560/11.4.1721

Camargo, J.B.D.A., G.S. Araújo, A.C.F. Cruz., T.G. Fonseca and D.M.S. Abessa. 2015. Use, development and improvement in the protocol of whole-sediment Toxicity Identification and Evaluation using benthic copepods. Mar. Pollut. Bull. 91(2): 511-517.

Carr, R.S., D.C. Chapman, C.L. Howard and J.M. Biedenbach. 1996. Sediment quality triad assessment survey of the Galveston Bay, Texas system. Ecotoxicology, 5:341-364.

Carr, R.S., P.A. Montagna, J.M. Biedenbach, R. Kalke, M.C. Kennicutt, R. Hooten and G. Cripe. 2000. Impact of storm water outfalls on sediment quality in Corpus Christi Bay, Texas. Environ. Toxicol. Chem. 19:561-574.

Carr, R.S., M.G. Nipper, W.J. Adams, W.J. Berry, G.A. Burton Jr., K. Ho, D.D. Macdonald, R. Scroggins and P.V. Winger. 2001. Summary of a SETAC technical workshop: porewater toxicity testing: biological, chemical, and ecological considerations with a review of methods and applications, and recommendations for future areas of research. March 2000. Pensacola, FL. Society of Environmental Toxicology and Chemistry (SETAC).

Cesar, A., C.D.S. Pereira, A.R. Santos, D.M.S. Abessa, N. Fernández, R.B. Choueri and T.A. Delvalls. 2006. Ecotoxicology assessment of sediments from Santos and São Vicente Estuarine System Brazil. Braz. J. Oceanogr., 54(1):55-63.

Cesar, A., D.M.S. Abessa, C.D.S. Pereira, A.R. Santos, N. Fernández, R.B. Choueri and T.A. Delvalls. 2007. A simple approach to integrate ecotoxicological and chemical data for the establishment of environmental risk levels. Braz. Arch. Biol. Techn. 52(1): 233-240

CETESB. 1985. Baixada Santista - Memorial descritivo. Carta do meio ambiente e de sua dinâmica. Relatório Técnico CETESB. São Paulo, SP.

CETESB. 1992. Água do mar - Teste de toxicidade crônica de curta duração com Lytechinus variegatus Lamarck, 1816 (Echinodermata: Echinoidea). Norma Técnica L5.250. São Paulo, CETESB.

Chapman, P.M. 1990. The sediment quality triad approach to determining pollution-induced degradation. Sci. Total Environ. 97/98:815-825.

Chapman, P.M. and Hollert, H. 2006. Should the Sediment Quality Triad Become a Tetrad, a Pentad, or Possibly even a Hexad? J. Soil. Sediment. 6(1):4-8.

Chapman, P.M., R.N. Dexter, H.B. Anderson and E.A. Power. 1991. Evaluation of effects associated with an oil platform, using the sediment quality triad. Environ. Toxicol. Chem. 10(3):407-424.

Comrey, A.L. and H.B. Lee. 1992. A First Course in Factor Analysis, 2nd ed. L. Erlbaum Associates, Hillsdale.

Dauvin, J.C. and T. Ruellet. 2009. The estuarine quality paradox: Is it possible to define an ecological quality status for specific modified and naturally stressed estuarine ecosystems? Mar. Pollut. Bull. 59:38-47.
Day, J.H. 1963. Polychaeta Of Southern Africa, Part 1. Errantia and Part 2. Sedentaria. London, British Museum (Nat. Hist.) Publ.

Del Valls, T.A. and P.M. Chapman. 1998. Site-specific quality values for the Gulf of Cádiz (Spain) and San Francisco Bay (USA), using the sediment quality triad and multivariate analysis. Cienc. Mar. 24(3):313-336.

Del Valls, T.A., J.M. Forja and A. Gómez-Parra. 1998. The use of multivariate analysis to link sediment contamination and toxicity data to establish sediment quality guidelines: an example in the Gulf of Cádiz (Spain). Cienc. Mar. 24(2):127-154.

Drake, P., F. Baldo, V. Sáenz and A.M. Arias. 1999. Macrobenthic community structure in estuarine pollution assessment on the Gulf of Cádiz (SW Spain): is the phylum-level meta-analysis approach applicable? Mar. Pollut. Bull. 38(11):1038-1047.

Dumbauld, B.R., K.M. Brooks and M.H. Posey. 2001. Response of an estuarine benthic community to application of the pesticide carbaryl and cultivation of pacific oysters (Crassostrea gigas) in Wilapa Bay, Washington. Mar. Pollut. Bull. 42(10):826-844.

Eaton, L. 2001. Development and validation of biocriteria using benthic macroinvertebrates for North Carolina estuarine waters. Mar. Pollut. Bull. 42(1):23-30.

Elliott, M. and V. Quitino. 2007. The estuarine quality paradox, environmental homeostasis and the difficulty of detecting anthropogenic stress in naturally stressed areas. Mar. Pollut. Bull. 54: 640-645.

Environment Canada, 1999. Canadian sediment quality guidelines for the protection of aquatic life. Summary tables. http://www. ec.gc.ca.

Fostier, A.H., J.R. Ferreira and M.O. de Andrade. 1995. Digestion for mercury determination in fish-tissues and botttom sediments by automated cold vapour atomic absorption spectrometry. Quim. Nova 18(5):425-430.

Fukumoto, M.M., M.M. Mahiques and M.G. Tessler. 2004. Bottom faciology and sediment transport in Santos Bay, Southeastern Brazil. J. Coast. Res., SI 39:1737-1740.

Fúlfaro, V.J. and W.L. Ponçano. 1976. Sedimentação atual do Estuário e Baía de Santos. um modelo geológico aplicado a projetos de expansão da zona portuária. In: Proceedings of $1^{\circ}$ Congresso Brasileiro de Geologia e Engenharia. 1976. Belo Horizonte, MG, Brazil. Sociedade Brasileira de Geologia, pp.67-90.

Fúlfaro, V.J., C.S. Requejo, P.M.B. Landim and R. Fúlfaro. 1983. Distribuição de elementos metálicos nos sedimentos da Baía de Santos, SP. In: 4th Simpósio Regional de Geologia. 1983. São Paulo, SP, Brazil. Sociedade Brasileira de Geologia, pp.275-289.

Gesteira, J.L.G. and J.C. Dauvin. 2000. Amphipods are good indicators of the impact of oil spills on soft-bottom macrobenthic communities. Mar. Pollut. Bull. 40(11):1017-1027.

Grebmeier, J.M., H.M. Feder and C.P. McRoy. 1989. Pelagic-benthic coupling on the shelf of the northern Bering and Chukchi Seas. II. Benthic community structure. Mar. Ecol. Progr. Ser. 51:253268.

Green, R. 1993. Application of repeated measures designs in environmental impact and monitoring studies. Aust. J. Ecol. 18:81-98.

Green, R. and P. Montagna. 1996. Implications for monitoring: study designs and interpretation of results. Can. J. Fish. Aquat. Sci. 53:2629-2636.

Gross, M.G. 1971. Carbon determination. In: Carver, R.E. (ed.), Procedures in Sedimentary Petrology. Wiley-Interscience, New York. pp. 573-596.

Guille, A. 1970. Benthic bionomy of continental shelf of the French Catalane Coast. II. Benthic communities of the macrofauna. Vie Milieu 21(8):149-280. 
Harari, J., R. Camargo and P.L. Cacciari. 2000. Resultados da modelagem numérica hidrodinâmica em simulações tridimensionais das correntes de maré na Baixada Santista. Rev. Bras. Recur. Hidr. 5(2):71-87.

Kim, B.S.M., A.B. Salaroli, P.A.L. Ferreira, J.R. Sartoretto, M.M. Mahiques and R.C.L. Figueira. 2016. Spatial distribution and enrichment assessment of heavy metals in surface sediments from Baixada Santista, Southeastern Brazil. Mar. Pollut. Bull. 103:333-338.

Kim, B.S.M., J.L.F. Angeli, P.A.L. Ferreira, J.R. Sartoretto, C. Miyoshi, M.M. Mahiques and R.C.L. Figueira. 2017. Use of a chemometric tool to establish the regional background and assess trace metal enrichment at Baixada Santista, southeastern Brazil. Chemosphere 166:372-379.

Koroleff, F. 1970. Direct determination of ammonia in natural waters as indophenol blue. In: Information on Techniques and Methods for Seawater Analysis. Charlottenlund, Internat. Counc. Exploration of the sea (Interlab. Rept. 3). pp. 19-22.

Lambshead, P.J.D., G.L.J. Paterson and J.D. Cage. 1997. Biodiversity professional. software package. The National History Museum and the Scottish Association for Marine Science.

Lamparelli, M.L., M.P. Costa, V.A. Prósperi, J.E. Bevilácqua, R.P.A. Araújo, G.G.L. Eysink and S. Pompéia. 2001. Sistema Estuarino de Santos e São Vicente. Relatório Técnico, CETESB. São Paulo, SP, Brazil.

Lana, P.C. 1984. Anelídeos poliquetos errantes do litoral do Estado do Paraná. Doctorate Thesis. Universidade de São Paulo, Instituto Oceanográfico.

Lardicci, C., S. Como, S. Corti and F. Rossi. 2001. Recovery of the macrozoobenthic community after severe dystrophic crises in a Mediterranean coastal lagoon (Orbetello, Italy). Mar. Pollut. Bull. 42(3):202-214.

Long, E.R. and P.M. Chapman. 1985. A sediment quality triad: measures of sediment contamination, toxicity and infaunal community composition in Puget Sound. Mar. Pollut. Bull. 16(10):405415.

Long, E.R., D.D. Macdonald, C.G. Severn and C.B. Hong. 2000 Classifying probabilities of acute toxicity in marine sediments with empirically derived sediment quality guidelines. Environ. Toxicol. Chem. 19(10):2598-2601.

Long, E.R., M.J. Hameedi, G.M. Sloane and L.B. Read. 2002. Chemical contamination, toxicity, and benthic community indices in sediments of the Lower Miami River and adjoining portions of Biscayne Bay, Florida. Estuaries 25 (4a):622-637.

Luiz-Silva, W., R.H.R. Matos, G.C. Kristosch and W. Machado. 2006. Variabilidade espacial e sazonal da concentração de elementos-traço em sedimentos do sistema estuarino de SantosCubatão (SP). Quim. Nova 29:256-263.

Magurran, A.E. 1988. Ecological Diversity And Its Measurements. Chapman and Hall, Princeton.

Martins, C.C., J.A. Ferreira, S. Taniguchi, M.M. Mahiques, M.C. Bícego, and R.C. Montone. 2008. Spatial distribution of sedimentary linear alkylbenzenes and faecal steroids of Santos Bay and adjoining continental shelf, SW Atlantic, Brazil: origin and fate of sewage contamination in the shallow coastal environment. Mar. Pollut. Bull. 56(7):1359-1363.

Martins, C.C., M.C. Bícego, M.M. Mahiques, R.C.L. Figueira, M.G. Tessler and R.C. Montone. 2010. Depositional history of sedimentary linear alkylbenzenes (LABs) in a large South American industrial coastal area (Santos Estuary, Southeastern Brazil). Environ. Pollut. 158(11):3355-3364.

Martins, C.C., M.C. Bícego, M.M. Mahiques, R.C.L. Figueira, M.G. Tessler and R.C. Montone. 2011. Polycyclic aromatic hydrocar- bons (PAHs) in a large South American industrial coastal area (Santos Estuary, Southeastern Brazil): sources and depositional history. Mar. Pollut. Bull. 63(5-12):452-458.

McCave, I.N. and J.P.M. Syvitski. 1991. Principles and methods of geological particle size analysis. In: Syvitski, J.P.M. (ed.), Principles, Methods, and Application of Particle Size Analysis. Cambridge University Press, Cambridge. pp. 3-21.

Mckenzie, H.A. and H.S. Wallace. 1954, The Kjeldahl determination of nitrogen: a critical study of digestion conditions. Aust. J. Chem. 7:55

Melo, S.L.R and D.M.S. Abessa. 2002. Testes de toxicidade com sedimentos marinhos utilizando anfípodos como organismo-teste. In: Nascimento, I., E.C.P.M. Sousa and M.G. Nipper (eds.), Ecotoxicologia Marinha: Aplicações No Brasil. Editora Artes Gráficas, Salvador, BA, Brazil. pp. 163-178.

Medeiros, P.M. and M.C. Bícego. 2004. Investigation of natural and anthropogenic hydrocarbon inputs in sediments using geochemical markers. I. Santos, SP_Brazil. Mar. Pollut. Bull. 49 761-769

Moreira, L.B., J.B.D.A. Camargo, B.B. Marques, C.C. Martins and D.M.S. Abessa. 2019. Evaluating multiple lines of evidence of sediment quality in an urban Marine Protected Area (XixováJapuí State Park, SP, Brazil). Environ. Sci. Poll. Res. 26(5): 4605-4617.

Moser, G.A.O. 2002. Aspectos da eutrofização no Sistema Estuarino de São Vicente-Santos: distribuição espaço temporal da biomassa e produtividade primária fitoplânctonica e transporte instantâneo de sal, clorofila-a, material em suspensão e nutrientes. Doctorate Thesis. Universidade de São Paulo, Instituto Oceanográfico. São Paulo, SP, Brazil.

Muniz, P., E. Danulat, B. Yannicell, J. García-Alonso, G. Medina and M.C. Bícego. 2004. Assessment of contamination by heavy metals and petroleum hydrocarbons in sediments of Montevideo Harbour (Uruguay). Environ. Int. 29:1019-1028.

Muniz, P., N. Venturini, A.M.S. Pires-Vanin, L.R. Tommasi and A Borja. 2008. Testing the applicability of a Marine Biotic Index (AMBI) to assessing the ecological quality of soft-bottom benthic communities, in the South America Atlantic region. Mar. Pollut. Bull. 50(6):624-637.

Nishigima, F.N., R.R. Weber and M.C. Bícego. 2001. Aliphatic and aromatic hydrocarbons in sediments of Santos and Cananéia, SP, Brazil. Mar. Pollut. Bull. 42(11):1064-1072.

Nonato, E.F. 1981. Contribuição ao conhecimento dos anelídeos poliquetas bentônicos da plataforma continental brasileira, entre Cabo Frio e o Arroio Chuí. Full Professor Thesis. Universidade de São Paulo, Instituto Oceanográfico.

Migotto, A.E. 1996. Benthic shallow-water hydroids (Cnidaria, Hydrozoa) of the coast of São Sebastião, Brazil, including a checklist of Brazilian hydroids. Zool. Verh. 306:3-125.

Ozolin'sh, A.V. 2000. Factors determining the spatial structure of benthic communities of a shallow bay. Russian J. Mar. Biol. 26(4):241-249.

Pearson, T.H. and R. Rosenberg. 1987. Feast and famine: Structuring factors in marine benthic communities. In: Gee, J.H.R. and P.S. Giller (eds.), The 27th Symposium of The British Ecological Society Aberystwyth 1986. Blackwell Scientific Publications, Oxford. pp. 373-395

Pereira, C.D.S., M.L. Martín-Díaz, J. Zanette, A. Cesar, R.B. Choueri, D.M.S. Abessa, M.G.M. Catharino, M.B.A. Vasconcellos, A.C.D. Bainy, E.C.P.M. Sousa and T.A. DelValls. 2011 Integrated biomarker responses as environmental status descriptors of a coastal zone (São Paulo, Brazil). Ecotox. Environ. Safe. $74: 1257-1264$ 
Pereira, C.D.S., D.M.S. Abessa, R.B. Choueri, V. Almagro-Pastor, A. Cesar, L.A. Maranho, M.L. Martín-Díaz, R.J. Torres, P.K. Gusso-Choueri, J.E. Almeida, F.S. Cortez, A.A. Mozeto, H.L.N. Silbiger, E.C.P.M. Sousa, T.A. DelValls and A.C.D. Bainy. 2014. Ecological relevance of sentinels' biomarker responses: A multilevel approach. Mar. Environ. Res. 96:118-126.

Pereira, C.D.S., L.A. Maranho, F.S. Cortez, F.H. Pusceddu, A.R. Santos, D.A. Ribeiro, A. Cesar and L.L. Guimarães. 2016. Occurrence of pharmaceuticals and cocaine in a Brazilian coastal zone. Sci. Total Environ. 548-549:148-154.

Prósperi, V.A. 2002. Comparação de métodos ecotoxicológicos na avaliação de sedimentos marinhos e estuarinos. Doctorate Thesis. Universidade de São Paulo, Escola de Engenharia de São Carlos. São Carlos.

Prósperi, V.A., G.G.J. Eysink, and L.M. Saito. 1998. Avaliação do grau de contaminação do sedimento ao longo do canal de navegação do porto de Santos. Relatório Técnico CETESB. São Paulo, SP, Brazil

Rachid, B.R.F. 2002. Avaliação ecotoxicológica dos efluentes domésticos lançados pelos sistemas de disposição oceânica da Baixada Santista. Doctorate Thesis. Universidade de São Paulo, Instituto Oceanográfico. São Paulo.

Reish, D.J. 1986. Benthic invertebrates as indicators of marine pollution: 35 years of study. IEE Oceans' 86 Conference Proceedings. Washington, DC. pp. 885-888.

Reish, D.J. 1993. Effects of metals and organic compounds on survival and bioaccumulation in two species of marine gammaridean amphipod, together with a summary of toxicological research on this group. J. Nat. Hist. 27:781-794.

Reiss, H., S. Birchenough, A. Borja, L. Buhl-Mortensen, J. Craeymeersch, J. Dannheim, A. Darr, I. Galparsoro, M. Gogina, H. Neumann, J. Populus, A.M. Rengstorf, M. Valle, G. van Hoey, M.L. Zettler and S. Degraer. 2015. Benthos distribution modelling and its relevance for marine ecosystem management. ICES J. Mar. Sci. 72(2):297-315.

Rios, E. 1984. Sea Shells Of Brazil. $2^{\text {nd }}$ Edition. Editora da FURG. Rio Grande, RS, Brazil.

Rosenberg, R., H.C. Nilsson and R.J. Diaz. 2001. Response of benthic fauna and changing sediment redox profiles over a hypoxic gradient. Estuar. Coast. Shelf. Sci. 53:343-350.

Santos, D.M., R.M. Gonçalves, M. Williams, R. Kookana, L. Buruaem, D.M.S. Abessa and M.R.R. Marchi 2018. Multiresidue determination and predicted risk assessment of contaminants of emerging concern in marine sediments from the vicinities of submarine sewage outfalls. Mar. Pollut. Bull. 129:299-307.

SAS Institute Inc. 1992. SAS/Lab Software: User's Guide, Version 6, First Edition, SAS Institute Inc., Cary, NC.

Smith, S.L., D.D. Macdonald, K.A. Keenleyside and C.L. Gaudet, 1996. The development and implementation of Canada sediment quality guidelines. In: M. Munawar and G. Dave (eds.), Development and Progress in Sediment Quality Assessment: Rationale, Challenges, Techniques and Strategies, SPB Academic Publishing, Amsterdam, The Netherlands. pp. 233249.

Sousa, E.C.P.M., D.M.S. Abessa, M.R. Gasparro, L.P. Zaroni and B.R.F. Rachid. 2007. Ecotoxicological assessment of sediments from the Port of Santos and the disposal sites of dredged material. Braz. J. Oceanogr. 55(2):75-81.

Suguio, K. 1973. Introdução à sedimentologia. Edgar Blücher, Edusp, São Paulo.

Tommasi, L.R. 1979. Considerações ecológicas sobre o Sistema Estuarino de Santos, São Paulo. Full Professor Thesys.
Universidade de São Paulo, Instituto Oceanográfico. São Paulo, SP, Brazil. 2 vols.

Torres, R.J., D.M.S. Abessa, F.C. Santos, L.A. Maranho, M.B. Davanso, M.R.L. Nascimento and A.A. Mozeto 2009. Effects of dredging operations on sediment quality: contaminant mobilization in dredged sediments from the Port of Santos, SP, Brazil. $J$. Soil. Sediment. 9:420-432.

UNEP. 1991. Determinations of petroleum hydrocarbons in sediments. United Nations Environment Programme. Reference methods for marine pollution studies.

USEPA. 1988. Short-term methods for estimating the chronic toxicity of effluents and receiving waters to marine and estuarine organisms. EPA-600/4-87-028. U.S. Environmental Protection Agency, Cincinnati, Ohio.

Van Dolah, R.F., J.L. Hyland, A.F. Holland, J.F. Rose and T.R. Snoots. 1999. A benthic index of biological integrity for assessing habitat quality in estuaries of the Southern USA. Mar. Environ. Res. 48:269-283.

Venturini, N. and L.R. Tommasi. 2004. Polycyclic aromatic hydrocarbons and changes in the trophic structure of polychaete assemblages in sediments of Todos os Santos Bay, Northeastern, Brazil. Mar. Pollut. Bull. 48:97-107.

Venturini, N.; P. Muniz, M.C. Bícego, C.C. Martins and L.R. Tommasi. 2008. Petroleum contamination impact on macrobenthic communities under the influence of an oil refinery: Integrating chemical and biological multivariate data. Estuar. Coast. Shelf. Sci. 78(3):457-467.

Weber, R.R.; E. Zanardi and M.C. Bícego. 1998. Distribuição e ocorrência dos hidrocarbonetos biogênicos e de petróleo, na água do mar superficial e nos sedimentos de superfície da região da plataforma interna do Canal de São Sebastião, SP, Brasil. Relat. Tec. Inst. Oceanogr. 43:1-14.

Weisberg, S.B., J.A. Ranasinghe, D.M. Dauer, L.C. Schaffner, R.J. Diaz. and J.B. Frithsen. 1997. An estuarine benthic index of biotic integrity (BIBI) for Chesapeake Bay. Estuaries 20(1):149158.

Whitfield, M. 1974. The hydrolysis of ammonia ions in sea water - a theoretical study. J. Mar. Biol. Assoc. UK 54:565-580.

Winger, P.V. and P.J. Lasier. 1991. A vacuum-operated pore-water extractor for estuarine and freshwater sediments. Arch. Environ. Con. Tox. 21:321-324.

Young, P.S. 1998. Catalogue of Crustacea of Brazil. Rio de Janeiro, Brazil. Museu Nacional, UFRJ.

Zamboni, A.J. and D.M.S. Abessa 2002. Tríade da qualidade de sedimentos. In: I.A. Nascimento, E.C.P.M. Sousa and M.G. Nipper (eds.), Ecotoxicologia Marinha: Aplicações No Brasil. Editora Artes Gráficas, Salvador. pp. 233-243.

Zar, J.H. 1984. Biostatistical Analysis. Prentice-Hall, Englewood Cliffs.

Received April 27, 2018

Revised March 22, 2019

Accepted May 24, 2019

\section{Supplementary material}

Table S1. Geographical coordinates and depths of each sampling station in the Santos Estuarine System.

Table S2. Physical-chemical parameters of water collected in each sampling station at Santos Estuarine System.

Table S3. Concentrations of Aliphatic Hydrocarbons (AHs) in sediments from the Santos Estuarine System (in $\mu \mathrm{g} / \mathrm{g}$ ). 
Table S4. Concentrations of Poly-Aromatic Hydrocarbons (PAHs) in sediments from the Santos Estuarine System (in $\mu \mathrm{g} / \mathrm{g})$.

Table S5. Physical chemical parameters of the overlying waters measured in the test-chambers during the whole sediment toxicity test with the amphipod T. viscana, using the sediments from the Santos Estuarine System.

Table S6. Physical chemical parameters of the pore water samples extracted from the sediments from the Santos Estuarine System and tested with embryos of the sea-urchin L. variegatus.

Table S7. Presence or absence of toxicity and estimations of the NH3 contents in pore water samples extracted from sediment collected in SES $(\mathrm{T}=$ toxic; $\mathrm{NT}=$ not toxic $)$

Table S8. Benthic species and their mean densities (in organisms per square meter) in the Santos Estuarine System.
Table S9. Variances extracted and Eigenvalues from the PCA with two matrices. using data of the Santos Estuarine System.

Table S10. First 3 Eigenvectors. each scaled to its standard deviation (correlation coefficients between scores for rows in the main matrix and the column variables). from the PCA ordination using data of the Santos Estuarine System. Values with bold fonts indicate significant correlations to the respective axes.

Table S11. Coordinates (Scores) of stations. according to the PCA run with two data matrices (data of the Santos Estuarine System).

Table S12. Pearson and Kendall Correlations with Ordination Axes $(\mathrm{N}=23)$. Gray cells are showing significant correlations to the respective axes.

The Appendix may be downloaded from www.akademiai. com. 